\title{
Morphology and Angiosperm Systematics in the Molecular Era
}

\author{
Peter K. Endress \\ Institute of Systematic Botany \\ University of Zurich \\ 8008 Zurich, Switzerland
}

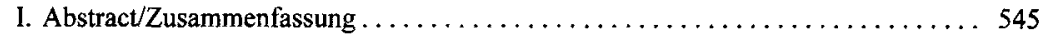

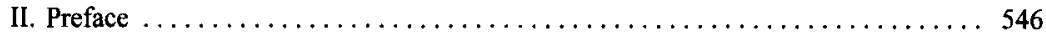

III. Introduction: The Role of Morphology in Phylogenetic and

Evolutionary Studies . .............................. 547

IV. Search for Special Structural Similarities ..................... 547

V. Cladistic Studies Based on Morphology and Combined Morphology and Molecules .................................... 548

VI. New, Morphologically Puzzling Relationships Derived from Molecular Studies .............................. 552

A. Families with Unexpected New Systematic Positions ............. 552

B. Asterids with Multistaminate and/or Multicarpellate Flowers ......... 554

VII. Character Evolution, Unusual Evolutionary Directions, and Evolutionary Lability ............................ 557

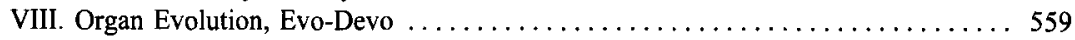

IX. Conclusions: New Opportunities and Goals of Morphology in

Plant Systematics and Evolutionary Biology ................... 560

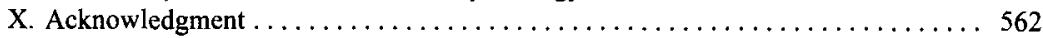

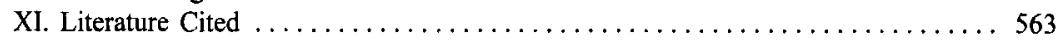

\section{Abstract}

Several ways in which morphology is used in systematic and evolutionary research in angiosperms are shown and illustrated with examples: 1) searches for special structural similarities, which can be used to find hints for hitherto unrecognized relationships in groups with unresolved phylogenetic position; 2) cladistic studies based on morphology and combined morphological and molecular analyses; 3) comparative morphological studies in new, morphologically puzzling clades derived from molecular studies; 4) studies of morphological character evolution, unusual evolutionary directions, and evolutionary lability based on molecular studies; and 5) studies of organ evolution. Conclusions: Goals of comparative morphology have shifted in the present molecular era. Morphology no longer plays the primary role in phylogenetic studies. However, new opportunities for morphology are opening up that were not present in the premolecular era: 1) phylogenetic studies with combined molecular and morphological analyses; 2) reconstruction of the evolution of morphological features based on molecularly derived cladograms; 3 ) refined analysis of morphological features induced by

Copies of this issue [68(4)] may be purchased from the NYBG Press, The New York Botanical Garden, Bronx, NY 10458-5128, U.S.A.; nybgpress@nybg.org. Please inquire as to prices. 
inconsistencies of previous molecular and molecular phylogenetic analyses; 4) better understanding of morphological features by judgment in a wider biological context; 5) increased potential for including fossils in morphological analyses; and 6) exploration of the evolution of morphological traits by integration of comparative structural and molecular developmental genetic aspects (Evo-Devo); this field is still in its infancy in botany; its advancement is one of the major goals of evolutionary botany.

\section{Zusammenfassung}

Verschiedene Möglichkeiten der Anwendung morphologischer Studien in der Systematik und Evolutionsforschung der Angiospermen werden gezeigt und mit Beispielen illustriert: 1) Suche nach aussergewöhnlichen morphologischen Ähnlichkeiten, die verwendet werden können als Anhaltspunkte für potentielle unerkannte phylogenetische Beziehungen bei Taxa mit noch wenig gesicherter Stellung; 2) kladistische Untersuchungen basierend auf kombinierten morphologischen und molekularen Analysen; 3) vergleichend-morphologische Untersuchungen in aufgrund von molekularen Analysen neuerkannten, morphologisch wenig untersuchten Clades; 4) Untersuchungen von morphologischer Merkmalsevolution, ungewöhnlichen evolutiven Richtungen und evolutiver Labilität, die aus molekularen Untersuchungen resultieren; 5) Untersuchungen der Evolution von Organen. Zukunftsaussichten: Morphologie spielt heute nicht mehr die Hauptrolle in der phylogenetischen Rekonstruktion. Es eröffnen sich jedoch neue Möglichkeiten für die Morphologie, die in der prämolekularen Zeit nicht vorhanden waren: 1) phylogenetische Studien basierend auf der Kombination von morphologischen und molekularen Datensätzen; 2) Rekonstruktion der Evolution morphologischer Eigenschaften basierend auf molekularen Kladogrammen; 3) verfeinerte Analysen morphologischer Eigenschaften in Fällen, wo morphologische und molekulare phylogenetische Analysen zu abweichenden Resultaten geführt haben; 4) besseres Verständnies morphologischer Eigenschaften in einem erweiterten biologischen Kontext; 5) vermehrte Verwendungsmöglichkeit von Fossilien; 6) Integration von vergleichend morphologischen und molekularen entwicklungsgenetischen Aspekten (EvoDevo); diese Forschungsrichtung steht in der Botanik erst am Anfang; ihre Förderung ist von besonderem Interesse.

\section{Preface}

This symposium, Structural Botany in Systematics, is dedicated to the memory of Bill Dickison, highly esteemed colleague and friend. My acquaintance with Bill was through the summer semester of 1982, when he was a guest professor at our department in Zurich and taught a course in systematic plant anatomy. The uniqueness of his approach was that he used all aspects of structure in his research. Today, researchers in structural botany are commonly wood anatomists, or flower morphologists, or palynologists, or seed anatomists, or vegetative morphologists. Bill did it all. Model families he studied in this way included Dilleniaceae (Dickison, 1967-1970, 1979; Rury \& Dickison, 1977; Dickison et al., 1978) and Cunoniaceae (Dickison, 1975a, 1975b, 1977, 1978, 1980, 1984, 1989; Rao \& Dickison, 1985a, 1985b; Rutishauser \& Dickison, 1989; Dickison \& Rutishauser, 1990; Hufford \& Dickison, 1992). Bill Dickison (1989) also provided a detailed discussion of the systematic position of Cunoniaceae and worked out an intrafamilial phylogenetic analysis, based on structural features (Hufford \& Dickison, 1992). A recent molecular analysis (Bradford \& Barnes, 2001) supports major parts of the morphological analysis. Bill's broad approach was also a basis for his unique book, Integrative Plant Anatomy (Dickison, 2000). 


\section{Introduction: The Role of Morphology in Phylogenetic and Evolutionary Studies}

The role of morphology in plant systematics has changed in the present molecular era. Phylogenetic studies began with morphology in the 1970s and 1980s but then became dominated by molecular methods in the late 1980s and the 1990s (for changes between 1950 and 2000, see Endress et al., 2000). Molecular studies triggered the development of refined cladistic software, which could, in turn, be used by new and more sophisticated morphological studies. It is advantageous to be able to base phylogenies on molecular data to prevent circular argumentation. However, we also have to realize that the entire endeavor of phylogenetic and evolutionary reconstruction is a large mosaic of detective work. For well-supported results, many steps may be necessary, with repeated cycles of reciprocal illumination. All parts should fit together at the end (see also Donoghue, 1994). In addition, one should not forget that new classifications (APG, 1998), shaped by molecular results, are built on the shoulders of those whose classifications were primarily based on morphology (e.g., Cronquist, 1981; Dahlgren et al., 1985; Kubitzki et al., 1993; Takhtajan, 1997; Thorne, 2000).

New opportunities for morphology in plant evolutionary biology have opened up thanks to results gained by molecular studies. Morphology no longer plays the primary role in phylogenetic studies. The focus of morphology is shifting to evolutionary reconstruction, where morphology is more efficient than earlier.

This also includes fossils. Paleobotanical studies gave and give fundamental insight into major relationships and are important means of questioning or strengthening results gained by the study of extant plants (e.g., Donoghue et al,, 1989). Fossils can be studied only structurally (except for relatively recent fossils, from which DNA can sometimes be retrieved; Soltis \& Soltis, 1993).

Among the milestones in angiosperm paleobotany that have contributed to phylogeny is Doyle's (1969) demonstration, in comparative stratigraphical studies, that triaperturate pollen began later in the fossil record than did uniaperturate pollen. This was a strong argument for the later origin of "higher" dicots than magnoliids (and monocots). In cladistic analyses it was subsequently shown that the taxa with triaperturate pollen form a monophyletic group (Donoghue \& Doyle, 1989a, 1989b), and the informal name eudicots was created (Doyle \& Hotton, 1991). This eudicot clade is well supported by molecular systematics. With the molecular recognition of the ANITA grade as basal in angiosperms (Qiu et al., 1999), it appeared in hindsight that fossils resembling extant representatives of ANITA members were present in the Early Cretaceous, though not in considerable quantities. These include leaves (Upchurch, 1984), Amborellalike pollen (Hughes \& McDougall, 1987; see also Doyle \& Endress, 2000), Illicium- or Nymphaeaceae-like seeds (Friis et al., 2000), and Nymphaeaceae-like plants (Mohr \& Friis, 2000) and flowers (Friis et al., 2001). Fossils also help to date divergence points in phylogenetic trees (Magallón et al., 1999; Bremer, 2000; Sanderson \& Doyle, 2001; Vinnersten \& Bremer, 2001).

\section{Search for Special Structural Similarities}

In the premolecular era, the search for and evaluation of structural similarities as potential synapomorphies was the only method for determining phylogenetic relationships. This was central to comparative morphology. Today it is overshadowed by molecular studies, because, with the new technologies, large data sets can be obtained more quickly and analyzed more easily. However, the search for structural similarities is still necessary and helpful. It may help 
in areas and at levels of the tree of life where molecular studies are difficult for some reason, and it may give additional support to molecular studies. Of course, structural cladistic studies are an additional way to proceed (see section V). Examples showing the significance of special structural similarities are given below.

Cronquist (1981) recognized a small family Mendonciaceae, close to but separate from Acanthaceae because of its fruit: an often unilocular drupe with only one or two seeds, in contrast to explosive capsules with two locules and four or more seeds. It was shown, however, that in Mendoncia the second locule is present in early development but then more or less obliterates (Fig. 1) (Schönenberger \& Endress, 1998). Furthermore, the early flower development greatly resembles that of Thunbergia of Acanthaceae. Thus Mendonciaceae should not be kept as a separate family. This was later supported by molecular studies, in which Mendoncia is sister to Thunbergia, and the two are sister to the core Acanthaceae (McDade et al., 2000).

Chase et al. (1996) found in a molecular study that the trash-can family Flacourtiaceae is polyphyletic, consisting of two or three clades, which also include some small former families. Two major clades are Achariaceae sensu lato and Salicaceae sensu lato. Bernhard and Endress (1999) showed that the androecium initiation pattern differs in these two clades. In Achariaceae sensu lato the stamens are initiated centripetally or almost simultaneously, whereas in Salicaceae sensu lato they are initiated centrifugally (Fig. 2).

All hamamelidaceous genera of the Southern Hemisphere are characterized by a unique feature of the anthers. Although they have four pollen sacs, organized into two thecae, each theca opens by a single valve, which is hinged on the ventral side of the theca (Fig. 3) (Endress, 1989a). To my knowledge, this pattern is not known in any other angiosperm and, thus, is unique. The combination of such a unique feature and the exclusive occurrence of these genera in the Southern Hemisphere (Australia, Madagascar, and Africa), in contrast to all other Hamamelidaceae, indicate that they represent a monophyletic group, which was separated from the northern rest of the family sometime in the Cretaceous and deserve to be recognized as a taxon (Endress, 1989b). This was later supported by molecular studies ( $\mathrm{Li} \&$ Bogle, 2001).

Floral structure in some Anisophylleaceae and Cunoniaceae is exceedingly similar (Fig. 4) (Matthews et al., 2001). In contrast, in molecular trees, Anisophylleaceae and Cunoniaceae appear far apart, Anisophylleaceae in Cucurbitales and Cunoniaceae in Oxalidales. From preliminary results of a comparative morphological study (M. Matthews, pers. obs.), Anisophylleaceae would fit better with Oxalidales than with Cucurbitales. Floral fossils with structural affinities to both Anisophylleaceae and Cunoniaceae, recently described from the Late Cretaceous of Sweden (Schönenberger et al., 2001), further emphasize potential close relationships between the two families. Currently, Anisophylleaceae are molecularly insufficiently known; only $r b c L$ was studied in two species. Thus, it will be important to extend molecular analyses to more genes, in order to see whether this will alter the phylogenetic position of the family.

\section{Cladistic Studies Based on Morphology and Combined Morphology and Molecules}

Some large morphological cladistic studies in angiosperms found relationships that were later confirmed by molecular studies. However, not many large morphological analyses had been carried out before the large $r b c L$ analyses by Chase et al. (1993), which then initiated the boom of molecular studies. Due to the complexity of morphological characters, building a sensible morphological data matrix is difficult. Stevens $(1991,2000)$ discussed difficulties in scoring morphological characters, based on his own experience with Ericales. Hawkins (2000) addressed formal problems in scoring morphological characters with a number of examples 


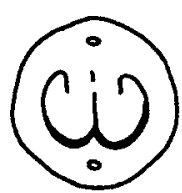

Mendoncia gllgiana

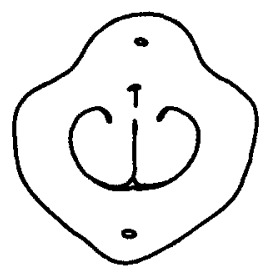

Mendoncia phytocrenoides
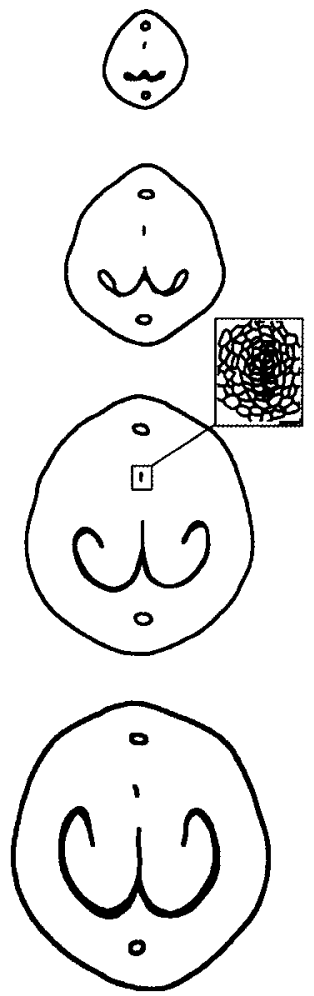

Mendoncia gilgiana

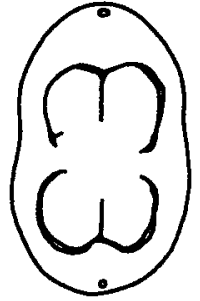

\section{Pseudocalyx macrophyllus}

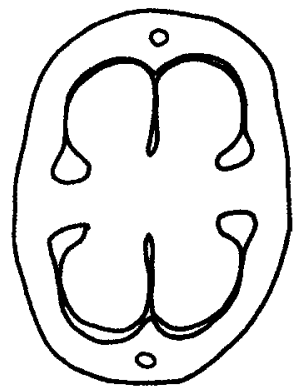

Thunbergia vogeliana
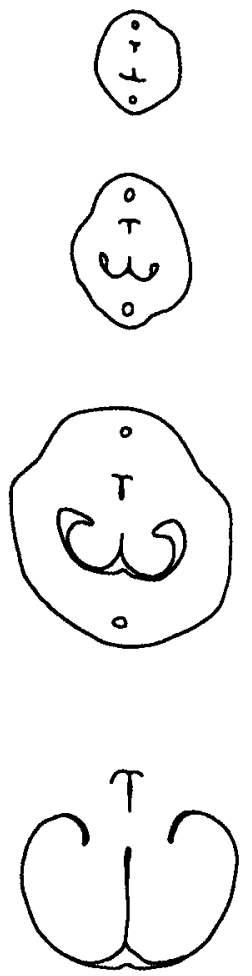

M. phytocrenoides

Fig. 1. Basal Acanthaceae, transverse sections of ovaries (from Schönenberger \& Endress, 1998). Upper figures: Pseudocalyx and Thunbergia have a two-locular ovary; Mendoncia has a unilocular ovary. Lower figures: Ovary development in two species of Mendoncia, showing the early development of two locules. In M. phytocrenoides, two almost equal locules are present in young stages; however, the upper (adaxial) one lags behind in development and does not bear fertile ovules. In $M$. gilgiana, the upper (adaxial) locule is minute from the beginning and almost obliterated at anthesis. 


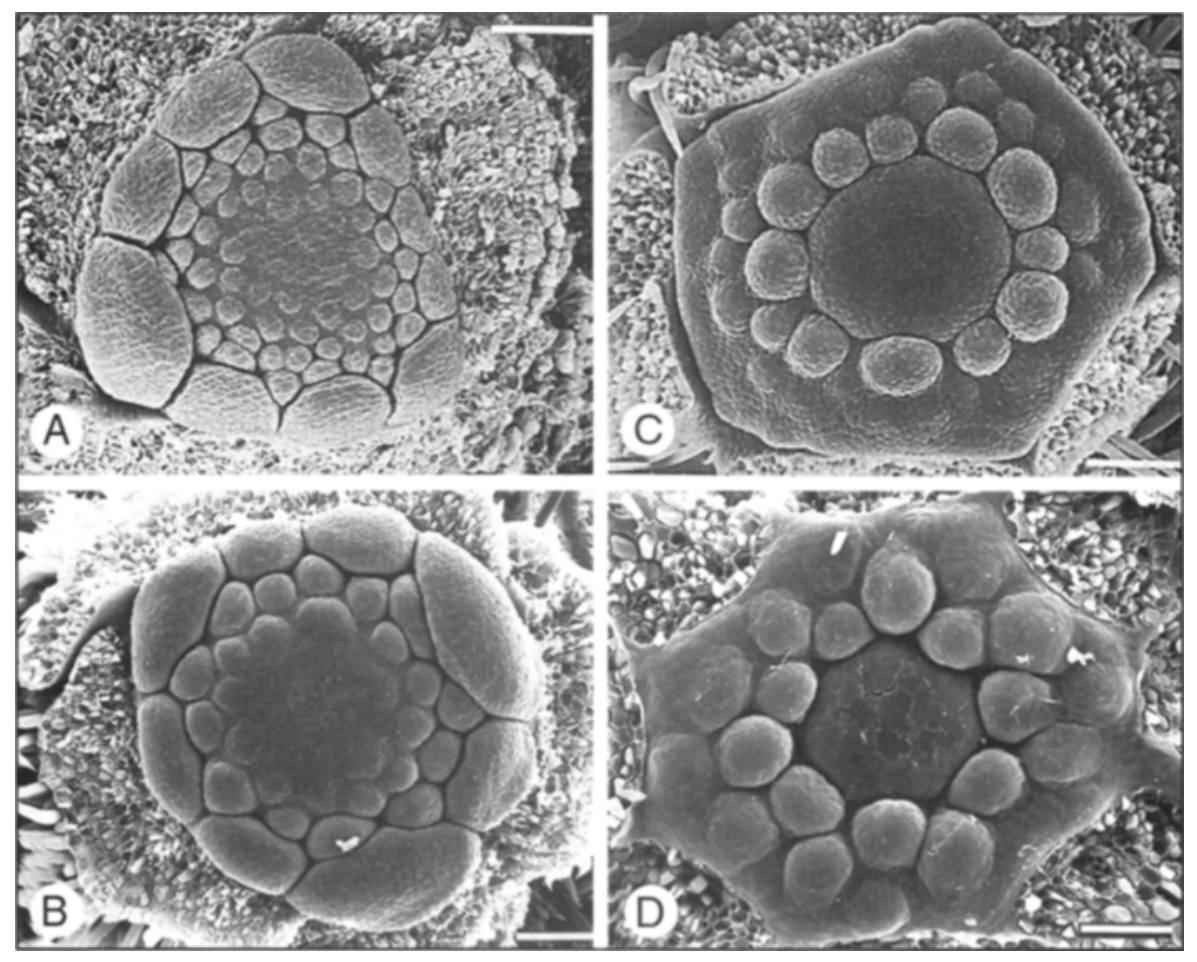

Fig. 2. "Flacourtiaceae," two different stamen-initiation patterns (from Bernhard \& Endress, 1999). A, B. Achariaceae sensu lato: centripetal stamen initiation. A. Camptostylus ovalis. B. Lindackeria dentata. C, D. Salicaceae sensu lato: centrifugal stamen initiation. C. Idesia polycarpa. D. Pseudoscolopia polyantha.

from published studies by various authors. An additional dimension is the degree of knowledge of global character distribution outside the group under study, which should improve both character selection and character-state scoring.

In the large structural study on Rosidae by Hufford (1992), several new results came out that were later confirmed by molecular studies, such as nonmonophyly of hamamelids, the close relationships of Loasaceae and Hydrangeaceae, and the position of Sarraceniaceae in asterids.

A morphological phylogenetic analysis by Tucker and Douglas (1994) found that Faboideae and Mimosoideae were monophyletic but that Caesalpinioideae formed a grade, with the tribe Cassieae being polyphyletic. This was later supported in an $r b c L$ analysis by Doyle et al. (2000). However, details in the topology of this caesalpinioid grade were different. The congruity of the structural and molecular trees in some major aspects is noteworthy. However, the differences in detail are also interesting, as they may help to elucidate problematical points in the coding of characters.

A cladistic analysis based on morphological characters had never been carried out for all angiosperms in sufficient detail before the large $r b c L$ analysis by Chase et al. (1993), although attempts to include all major angiosperm lineages in morphological cladistic analyses had been 


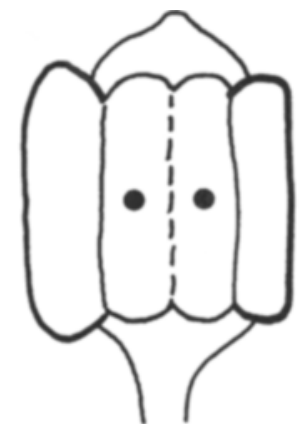

A

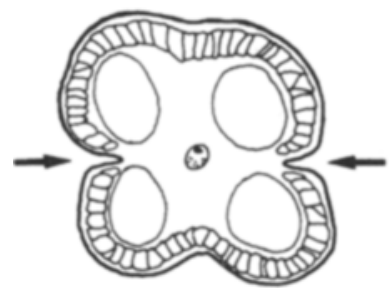

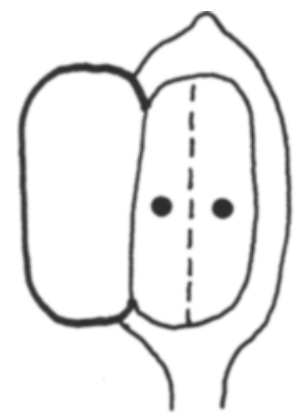

B

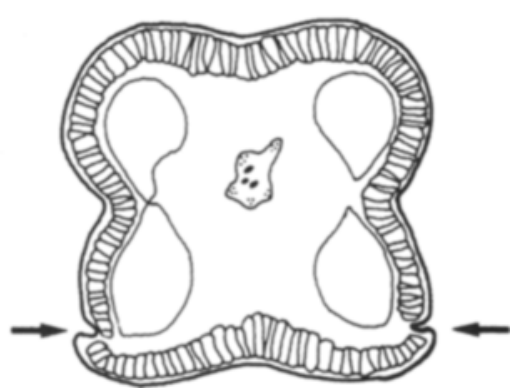

Fig. 3. Hamamelidaceae, different anther structure. Upper figures: open anthers from the side; each dot designates a pollen sac. Lower figures: Transverse sections of closed anthers; each arrow points to a dehiscence line (from Endress, 1989a). A. Anther with two valves per theca and a normal, central dehiscence line (in most Hamamelidaceae). B. Anther with one valve per theca and a unique, excentric dehiscence line (exclusively in all genera of the Southern Hemisphere).
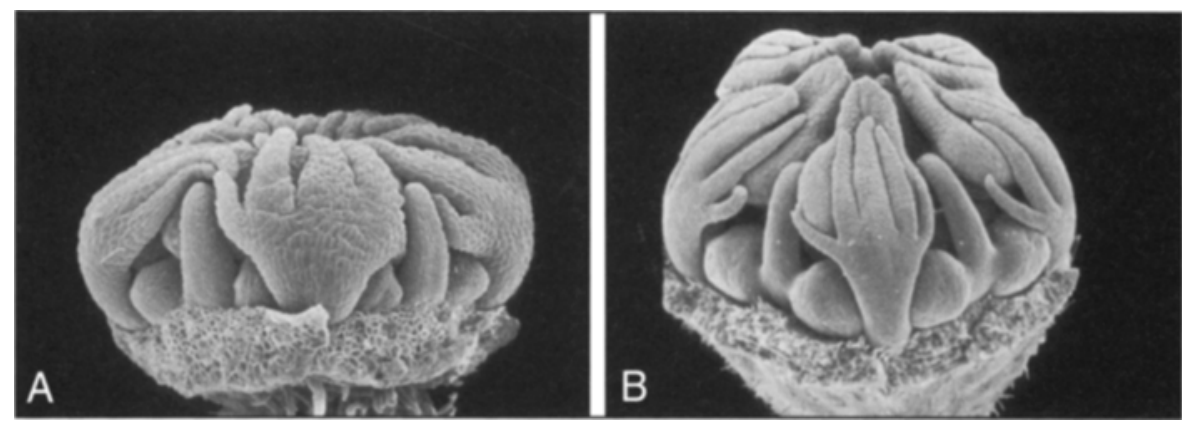

Fig. 4. Anisophylleaceae (Cucurbitales) and Cunoniaceae (Oxalidales), young flowers (sepals removed), showing digitate petals, protruding nectaries, and incurved stamens (from Matthews et al., 2001). A. Anisophyllea disticha (Anisophylleaceae). B. Ceratopetalum gummiferum (Cunoniaceae). 
conducted by Dahlgren and Bremer (1985) and by Donoghue and Doyle (1989a, 1989b). Later, Doyle et al. (1994), Nandi et al. (1998), and Doyle and Endress (2000) provided more studies with increasing amounts of data; in addition, these three studies combined and discussed molecular and structural data sets. Another large combined data set and analysis of monocots is that by Stevenson et al. (2000). Combination of molecular and morphological data appear to be commonly more robust than molecular data alone (Donoghue \& Sanderson, 1992; Nandi et al., 1998; Chase et al., 2000; Sytsma \& Hahn, 2000; Sytsma \& Pires, 2001).

\section{New, Morphologically Puzzling Relationships Derived from Molecular Studies}

\section{A. FAMILIES WITH UNEXPECTED NEW SYSTEMATIC POSITIONS}

Molecular systematics has revealed some surprising relationships that had not been suggested before. Some of these cases also show how convoluted the detective story of systematic research can be-and the story may not be concluded today.

Dickison and Baas (1977) were the first to recognize the affinity of Paracryphiaceae to its closest relative (that was later supported by molecular systematics; Savolainen et al., 2000), but the global position of this clade was not discovered until later. Paracryphia was first described as Ascarina alticola (Chloranthaceae) (Schlechter, 1906). It was found to be congeneric with Paracryphia by van Steenis (1950). Paracryphia had originally been described and positioned in Eucryphiaceae (Baker, 1921). This was supported by Swamy (1953). However, Dickison and Baas (1977) found similarities with Sphenostemonaceae, Actinidiaceae, and Theaceae, and Schmid (1978) found affinities with Actinidiaceae; Hufford (1992) placed the family as sister to Dilleniaceae and Theaceae. The big surprise came most recently from an rbcL analysis in which Paracryphia was found to be sister to Sphenostemon and this clade sister to Desfontainia and Polyosma in Dipsacales (Savolainen et al., 2000). All four genera are in monogeneric families. In the mature fruit of Paracryphia the carpels separate from a persistent central column (as in Medusagyne) (Cronquist, 1981; Endress, pers. obs.); the position of Medusagyne is not yet clear (APG, 1998; Savolainen et al., 2000). The clade consisting of Paracryphia, Sphenostemon, Polyosma, and Desfontainia is striking, because none of the four genera had previously been positioned near Dipsacales.

Not only Paracryphia but also Sphenostemon (Sphenostemonaceae) was once believed to be a primitive angiosperm. When Sphenostemon was first described it was placed in Rutaceae (Baillon, 1875a) or Aquifoliaceae ("Ilicineae") (Baillon, 1875b). However, one of its species was later described as a new genus, Idenburgia, in Trimeniaceae (Monimiaceae) (Gibbs, 1917). Van Steenis (1952) and Bailey and Swamy (1953) found another genus, Nouhuysia, to be congeneric with Idenburgia; Nouhuysia had originally been described as a genus of Guttiferae (Lauterbach, 1912). Van Steenis and Erdtman finally sank Nouhuysia (plus Idenburgia) into Sphenostemon and confirmed its likely position in Aquifoliaceae (van Steenis, 1955). This position was maintained by Cronquist (1981) and Takhtajan (1997), although Bailey (1956) and Metcalfe (1956) (while supporting the Nouhuysia-Sphenostemon alliance) had questioned a relationship with Aquifoliaceae on anatomical grounds. As mentioned before, most recently, Sphenostemon surprisingly appeared in Dipsacales, based on $r b c L$ (Savolainen et al., 2000). Although both Aquifoliales and Dipsacales are in euasterids II (APG, 1998) they do not seem to be closely related (Savolainen et al., 2000).

Of the other two genera in this new clade within Dipsacales, Polyosma was originally in Saxifragaceae sensu lato (Escallonioideae) (Engler, 1930), Desfontainia in Loganiaceae (Leeuwenberg \& Leenhouts, 1980). At first glance, these four monogeneric families seem to 
be quite different from one another: Desfontainia has strongly sympetalous, tubular flowers (Fig. 5D); the flowers of the other three genera have free perianth parts, although in Polyosma they are also tubular (Fig. 5C); flowers of Paracryphia (Fig. 5A) and Sphenostemon (Fig. 5B) are not differentiated into calyx and corolla (some species of Sphenostemon have two series of perianth parts; Jérémie, 1997). However, their structure is poorly known in detail. The molecular results cry out for a comparative morphological study of this curious assemblage of strangers, and the apparent morphological disparity, in turn, demands the inclusion of more genes in molecular analyses. Desfontainia occurs in the Andes. Paracryphia, Sphenostemon, and Polyosma are all from the Western Pacific region; all three have species in New Caledonia; the monotypic Paracryphia is endemic there. Interestingly, all three genera that are represented in New Caledonia have "primitive" wood, with more than 100 perforation bars in the end walls of the vessel elements (cf. Takhtajan, 1997). Desfontainia also has up to 65 perforation bars (Mennega, 1980).

Eupteleaceae were long regarded as a member of Trochodendrales or Hamamelidales in hamamelidids (e.g., Hallier, 1903; Takhtajan, 1959; Endress, 1986). Surprisingly, molecular systematic studies placed Eupteleaceae in Ranunculales, at first in an unresolved position (Chase et al., 1993; Drinnan et al., 1994) but then in a grade between Papaveraceae (at the base) and all other Ranunculales (Hoot \& Crane, 1995; Soltis et al., 2000). Eupteleaceae are characterized by a special wind-pollination syndrome (Fig. 6A, B) (Endress, 1969), which is also known in some Hamamelidaceae and related families. However, it is of interest that within Papaveraceae, Bocconia and Macleaya have a similar floral (wind-pollination) syndrome, with reduced perianth, long, hanging anthers, and relatively large stigma with long papillae (Fig. 6C, D). A similar syndrome appears in some species of Thalictrum in Ranunculaceae. Thus, the floral syndrome of Eupteleaceae is not unique in Ranunculales; rather, it apparently evolved several times within this order. However, a striking difference that still remains is that Eupteleaceae are sizable trees, whereas this trait is otherwise not known in Ranunculales.

Vochysiaceae were earlier included in Polygalales (close to Trigoniaceae and Malpighiaceae) (Cronquist, 1981). Based on $r b c L$ molecular studies by Conti et al. $(1996,1997)$ they came out in Myrtales, as sister to Myrtaceae s.str. It was unexpected to find a family with highly elaborated, strongly monosymmetric, or even asymmetric flowers that have a spur in Myrtales and, even more, as sister to Myrtaceae s.str., which have relatively unelaborated, polysymmetric flowers.

An especially surprising result was to find Balsaminaceae sister to Marcgraviaceae/Tetrameristaceae/Pellicieraceae (Soltis et al., 2000). Balsaminaceae had already come out in Ericales (but not with these families) in Chase et al. (1993), Olmstead et al. (1993), and Soltis et al. (1997). This position was not found in structural analyses. Floral morphology is very different, again monosymmetric and elaborate versus polysymmetric and simpler (in the other families). In addition, the flowers are delicate in Balsaminaceae but tough in Marcgraviaceae. This superficial impression of unrelatedness is increased by the fact that the two best-known genera of Marcgraviaceae, Marcgravia and Norantea, have multistaminate flowers (Gilg \& Werdermann, 1925), in contrast to Balsaminaceae and the other two families. Thus, a comparative morphological investigation would again be important.

Gunneraceae, formerly often placed with Haloragaceae and Myrtales, came out as sister of Myrothamnaceae in a combined morphological and molecular analysis by Drinnan et al. (1994). This too is supported by more recent data (Soltis et al., 2000; Savolainen et al., 2000). Morphologically, the two families seem to be very different (Endress \& Igersheim, 1999). However, the structure of Gunnera species with small growth forms has not been well studied (Wilkinson, 2000), and these species may have more plesiomorphic features within the genus, 


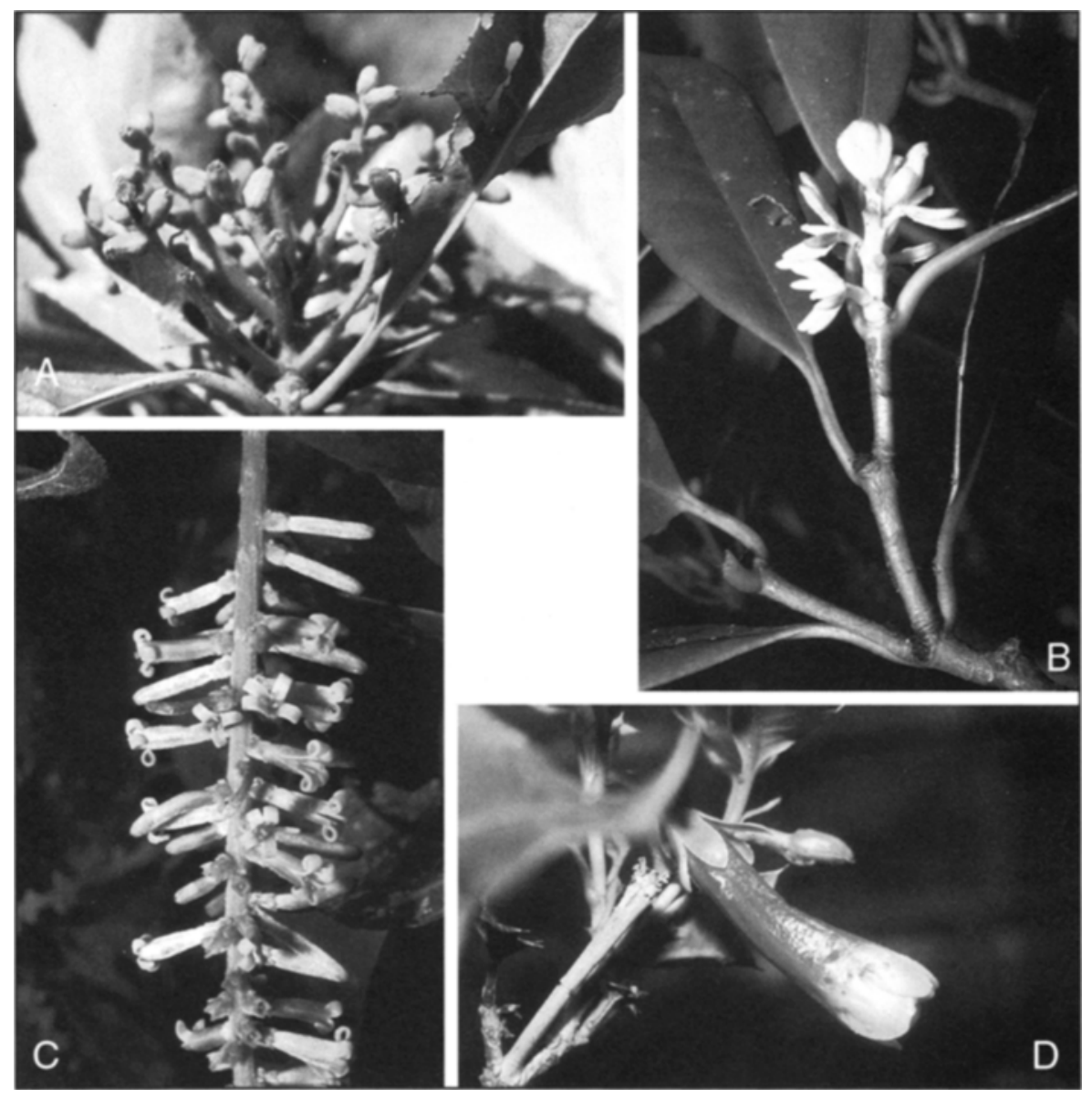

Fig. 5. Four families that form a new clade within Dipsacales, based on $r b c L$ (Savolainen et al., 2000), but exhibit highly diverging floral structures (all from collections of the author). A. Paracryphia alticola (Paracryphiaceae). B. Sphenostemon lobosporus (Sphenostemonaceae). C. Polyosma aff. alangiacea (Polyosmaceae). D. Desfontainia spinosa (Desfontainiaceae).

which may then be more similar to those of Myrothamnus. In fact, Gunnera herteri, a small annual herb, comes out basal in the genus in the study by Wanntorp et al. (2001).

\section{B. ASTERIDS WITH MULTISTAMINATE AND/OR MULTICARPELLATE FLOWERS}

We must become accustomed to the fact that clades are more diverse than we thought. We were brought up with some preconceptions about the structure of some larger groups, such as the structure of an asterid, of a member of Dipsacales, or of a member of Ericales. These ideas are, of course, in general still valid. However, there may be strongly deviating exceptions from the general picture in each group.

It is relatively unusual to have flowers with numerous stamens in asterids. This is probably the reason why most such taxa that have turned out to be asterids in molecular studies, were 

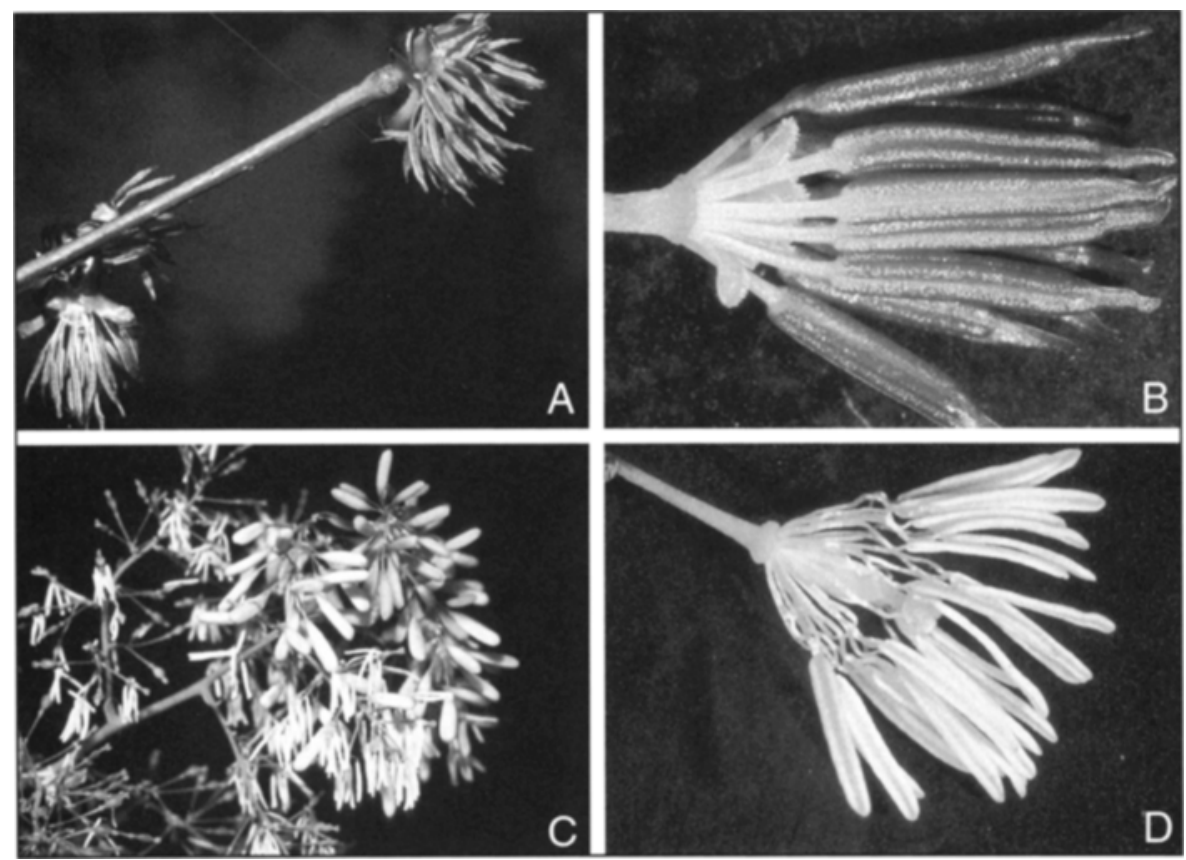

Fig. 6. Two members of Ranunculales with a wind-pollination syndrome. A, B. Euptelea polyandra (Eupteleaceae). A. Branch with inflorescences. B. Single flower. C, D. Macleaya cordata (Papaveraceae). C. Part of an inflorescence. D. Single flower.

formerly classified in rosids or dilleniids. However, taxa with multistaminate flowers are not randomly distributed among asterids. They are concentrated in the more basal orders, Cornales and Ericales (for phylogeny, cf. Albach et al., 2001). Most of these families are not closely related to each other. This is also reflected by the fact that they have different androecium initiation patterns. Both systematic distribution and different patterns indicate that polyandry in asterids has evolved a number of times and even more than once within some families.

Here I consider asterid flowers with more than ten stamens as multistaminate (if the corolla is pentamerous). In Ericales, at least nine families have consistently or partly multistaminate flowers: Theaceae (Fig. 7A), Lecythidaceae (Fig. 7B), Marcgraviaceae (Fig. 7C), Fouquieriaceae (Fig. 7D), Actinidiaceae (Fig. 7E), Ebenaceae, Sarraceniaceae, Styracaceae, and Symplocaceae. These families do not form a clade but appear rather scattered in the Ericales (Savolainen et al., 2000; Albach et al., 2001). Thus multistaminate androecia seem to have evolved several times within Ericales. This is also indicated by disparate patterns of androecium development. Lecythidaceae and some Theaceae are characterized by a large number of stamens (hundreds, in extreme cases) and a centrifugal stamen initiation pattern, combined with a ring primordium (Lecythidaceae: Hirmer, 1918; Leins, 1972; Endress, 1994; Tsou, 1994; Theaceae: Vishenskaya, 1980a, 1980b; Erbar, 1986; Sugiyama, 1991; Tsou, 1998). In Symplocaceae (Caris et al., 2001) and some Theaceae (Erbar, 1986; Tsou, 1998), five stamen fascicles are formed. In Actinidia (Actinidiaceae), the stamens are initiated more or less simultaneously (van Heel, 1987). In Ebenaceae, Fouquieriaceae, Marcgraviaceae, Sarraceniaceae, and Styracaceae, polyandry is less pronounced, and early development has not been studied. In Fouquieriaceae (Henrickson, 

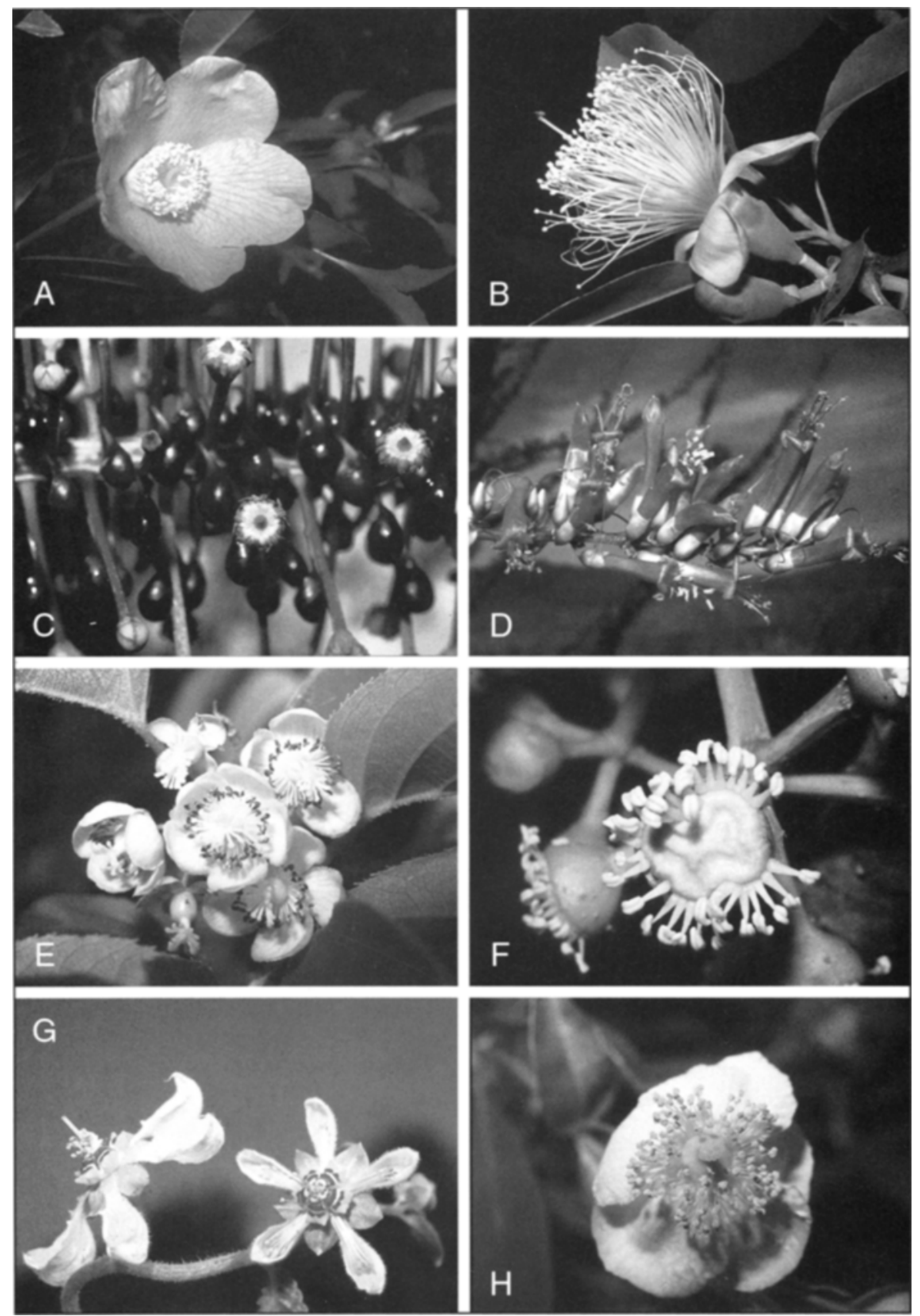

Fig. 7. Asterids with multistaminate flowers. A. Camellia sinensis (Theaceae, Ericales). B. Planchonia careya (Lecythidaceae, Ericales). C. Schwartzia (Norantea) brasiliensis (Marcgraviaceae, Ericales). D. Fouquieria splendens (Fouquieriaceae, Ericales). E. Actinidia arguta (Actinidiaceae, Ericales). F. Tupidanthus calyptratus (Araliaceae, Apiales). G. Blumenbachia hieronymi (Loasaceae, Cornales). H. Carpenteria californica (Hydrangeaceae, Cornales). 
1972) and Styracaceae (Dickison, 1993), stamens are in one series. In Marcgraviaceae, they are in two series in Marcgravia (Endress, pers. obs.). The two multistaminate families of Cornales, Loasaceae (Fig. 7G) and Hydrangeaceae (Fig. 7F), are sisters (Soltis et al., 2000; Moody et al., 2001). In Loasaceae, the polyandrous genera do not form a monophyletic group (Moody \& Hufford, 2000; Moody et al., 2001). Polyandry was first described as centrifugal and centripetal (Leins \& Winhard, 1973). However, Hufford (1990) found a unifying pattern in the family. In Hydrangeaceae, too, the genera with multistaminate flowers (Kappeler, 1995; Hufford, 1997; Roels et al., 1997) do not seem to form a single clade (Hufford et al., 2001). Among Apiales, Araliaceae (Fig. 7F) contain several genera with multistaminate flowers; in three genera there are species with 100 or more stamens (Eyde \& Tseng, 1971). Among Gentianales, there are a few multistaminate genera in Rubiaceae. Dialypetalanthus has a tetramerous perianth but 16-25 stamens; it is also unusual in that it has free petals (Piesschaert et al., 1997). Originally the genus had been placed in Myrtales. However, Piesschaert et al. (1997) placed it in Gentianales, preferably Rubiaceae, based on structural features, and an $r b c L$ analysis supported a highly nested position in Rubiaceae (Fay et al., 2000). Theligonum and Coprosma (both Anthospermeae, Rubiaceae) may have more than 10 stamens, and Theligonum to up to 30 (Rutishauser et al., 1998).

Still less common are asterids in which flowers are multicarpellate and thus have more than the usual 2-5 carpels. Apart from Paracryphiaceae, other aspects of which were addressed above, the position of these groups in asterids was never problematical. This may be because an increase in carpel number in a syncarpous gynoecium has less effect on the general appearance of flowers than does an increase in number of free stamens. Paracryphiaceae (Dipsacales; cf. Savolainen et al., 2000) have 8-15 carpels (Fig. 8A) (Dickison \& Baas, 1977). The parasitic Lennoaceae (now in Boraginaceae; APG, 1998) have up to 17 carpels (Fig. 8B) (Suessenguth, 1927). Some Ericaceae (Ericales; also including Empetrum and some epacrids) (Cronquist, 1981) and Sapotaceae (Steyn et al., 1991) have up to 10 carpels. A number of genera in Araliaceae (Apiales) are multicarpellate, the most extreme case being Tupidanthus, with up to more than 200 carpels (Fig. 8D) (Eyde \& Tseng, 1971). That they are all more or less highly nested in Araliaceae is supported by molecular studies (Plunkett et al., 1997; Wen et al., 2001). Among Rubiaceae, in several tribes there are genera with more than 5 carpels. In Timonius there are more than 20 (Robbrecht, 1988). However, it is not clear whether each uniovulate locule corresponds to a carpel. The same is true for the aberrant genus Nolana (earlier in Nolanaceae, but now in Solanaceae; APG, 1998), in which the seemingly 10 or more carpels may have arisen through subdivision of two original carpels (Fig. 8C) (Huber, 1980).

\section{Character Evolution, Unusual Evolutionary Directions, and Evolutionary Lability}

Once a solid phylogenetic framework is established in a group, it becomes possible to study character evolution. This is an important new opportunity for morphological studies. The result of character-optimization analyses has to be interpreted in a biological context. It may also help to find problems in the definition of character states, which, in turn, may lead to deeper morphological studies from a new perspective. Such studies also show that evolution is less unidirectional than was often believed in almost dogmatic assumptions.

The first case relates to ovary position. It was commonly believed that there is a general evolutionary direction from superior to inferior, for two reasons: 1) the inferior condition is more complicated than the superior, so it must be derived from the superior; and 2) most of the commonly known basal angiosperms have superior ovaries, whereas several large, conspicu- 
A
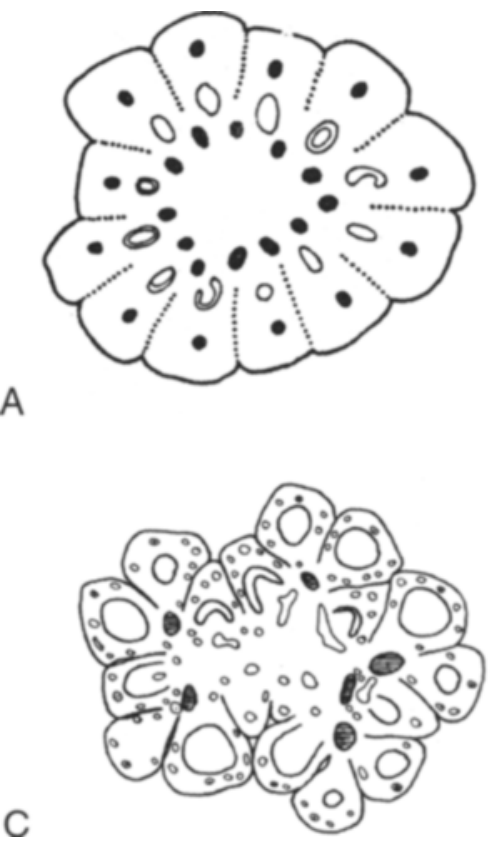

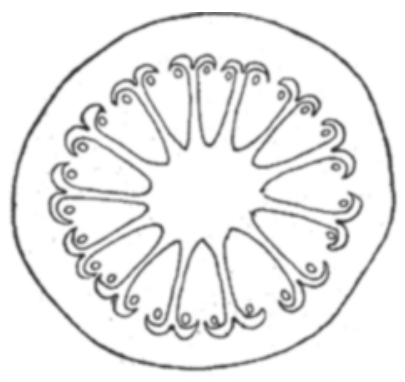

B

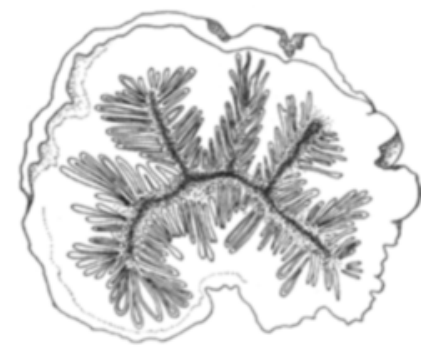

Fig. 8. Asterids with multicarpellate flowers, transverse sections of ovaries. A. Paracryphia alticola (Paracryphiaceae, Dipsacales) (from Dickison \& Baas, 1977). B. Lennoa madreporoides (Boraginaceae, Boraginales) (from Suessenguth, 1927). C. Nolana paradoxa (Solanaceae, Solanales) (from Huber, 1980). D. Tupidanthus calyptratus (Araliaceae, Apiales) (from Eyde \& Tseng, 1971).

ous, advanced families or orders, such as Orchidaceae, Asteraceae, Rubiaceae, Asterales, Dipsacales, and Zingiberales, are characterized by inferior ovaries.

However, comparative morphological studies have long emphasized that the opposite evolutionary direction also occurs: for instance, in superior genera that are nested in inferior families. These interpretations have been supported by molecular systematic studies in the families in which such studies were conducted. Examples include Tetraplasandra (Araliaceae) (Eyde \& Tseng, 1969), supported by molecular studies (Costello \& Motley, 2001; Plunkett \& Lowry, 2001), and Gynotroches (Rhizophoraceae) (semi-inferior to superior) (Juncosa, 1988), supported by molecular studies (Schwarzbach \& Rickleffs, 2000). Moreover, numerous genera of Rubiaceae (Pagamea, Coryphothamnus, Tresanthera, Canthiopsis, Mastixiodendron, Synaptantha, Lucya, Leptomischus, Pleiocraterium, Arcytophyllum, Oldenlandia spp., Astiella spp., and Mitrasacmopsis) have half-inferior or almost superior ovaries (Robbrecht, 1988: 88). In Gaertnera the ovary is inferior at anthesis but superior in fruit (Igersheim et al., 1994); molecular systematic studies have dealt with, for instance, Gaertnera (Bremer \& Manen, 2000) as well as Oldenlandia (Bremer et al., 1995) and have supported the evolutionary direction of inferior to superior. Among Haemodoraceae, Wachendorfia, Barberetta, Schiekia, and Pyrrorhiza have secondarily superior ovaries (Simpson, 1994, 1998).

It is also striking that flowers with inferior ovaries occurred as early as in the Lower Cretaceous, as evident from Hedyosmum-like fossil flowers (Friis et al., 1994; Crane et al., 1995). They are well supported because the fossils also contain the unique pollen type of Hedyosmum. 
Gustafsson and Albert (1999) showed evolutionary direction in ovary position for various groups above the genus level. The basal state in Asterales is inferior. But superior ovaries have evolved in taxa of at least six families: Pittosporaceae, Escalloniaceae, Menyanthaceae, Goodeniaceae, Phellinaceae, and Campanulaceae.

A second case of "unorthodox" evolutionary direction is the evolution of apocarpous gynoecia from syncarpous ancestors. This is obvious, for example, in Rutaceae, Simaroubaceae, Sterculieae-Malvaceae, and Apocynaceae s.l. However, in these cases the tips of the free carpels become postgenitally united before anthesis, and this united part apparently maintains a compitum. In this way a functional disadvantage caused by the loss of syncarpy is circumvented. The bond is usually only transient, so that the gynoecium is completely apocarpous before and after anthesis. This unusual evolutionary direction has been discussed by Endress et al. (1983), and it was later supported by the phylogenetic topology of these families resulting from molecular studies (e.g., Soltis et al., 2000).

A third case is the evolution of polysymmetric flowers from monosymmetric ancestors, which seems to be more common than previously believed (Ree \& Donoghue, 1999). Different mechanisms may be involved in this evolutionary direction. It is effected simply by reduction of the number of the perianth parts; for example, in Plantago and Callitriche (Veronicaceae) (Donoghue et al., 1998; Endress, 1998, 1999; Reeves \& Olmstead, 1998) and in Bersama (Melianthaceae) (Ronse Decraene et al., 2001). In Sibthorpia (Veronicaceae) the flowers are simplified without organ number reduction but organ number (sepals, petals, and stamens) has become unstable (Endress, 1998). The most often discussed case is peloriae, in which elements of the monosymmetric ancestral flowers are often used for a derived polysymmetric construction (e.g., Coen, 1996; Cubas et al., 1999; Möller et al., 1999; Endress, 2001a).

Another problem is evolutionary lability, in which evolutionary changes back and forth may easily take place. This is the case, for example, in ovary position, the first trait discussed in this section. Within some families or even genera, ovary position may be highly labile. Such evolutionary lability has often not been explored enough. If there is incongruity of the grid of sampling of taxa with the speed of evolutionary change, this may lead to wrong results in character evolution. In only a very few examples were labile characters traced and discussed within genera at species level. Such evolutionary lability was shown in studies at the species level for two genera in Saxifragaceae, Lithophragma (Kuzoff et al., 1999, 2001) and Chrysosplenium (Soltis et al., 2001). These studies show how a more superior position evolved several times from more inferior positions within one genus. Saxifragaceae seem to be especially plastic in the position of the ovary. This is also the case in other families of Saxifragales, such as Hamamelidaceae (Corylopsis; Morley \& Chao, 1977; Endress, 1989b; Parrotia; Endress, pers. obs.), Paeoniaceae and Crassulaceae (Gustafsson \& Albert, 1999). Evolutionary lability in the degree of fusion of petals and stamens was shown in detail for the Gentianella-SwertiaHalenia clade (von Hagen \& Kadereit, 2002).

\section{Organ Evolution, Evo-Devo}

There are some unsolved fundamental problems in flower evolution, such as the origin of the floral organs: perianth parts, stamens, and carpels. It may be expected that the study of fossils and the application of Evo-Devo, which is still in its infancy in botany, will bring new results. I will address here two questions in the interpretation of perianth organs.

In the core eudicots the perianth is differentiated into calyx and corolla. Delimitation is commonly not problematic, because calyx and corolla both occur in an isomerous whorl or series of sepals and petals. However, in basal angiosperms there are two major problems. 
One problem is that sepals and petals are not clearly differentiated, and the perianth organs are referred to as tepals, even if the inner ones are different from the outer ones and petaloid. But then, what differentiates these perianth organs from real sepals and petals? In contrast to stamens and carpels, which are strictly defined by their sexual functions, strict definition by function is not possible for sepals and petals or for tepals. A combination of anatomical and histological features loosely characterizes these organ categories. One of the most interesting features is a developmental one. Typical petals in basal eudicots and in basal core eudicots, though initiated in the normal acropetal sequence, are conspicuously retarded and lag behind sepals and stamens for some time during bud development (Fig. 9C, D). The inner perianth organs of basal angiosperms do not show this retardation, even if they are petaloid. But there are exceptions: in Cabomba (Nymphaeales) (Fig. 9A, B) (Hiepko, 1965; Tucker \& Douglas, 1996; Endress, 2001b) and Saruma (Piperales) (Leins \& Erbar, 1995) the inner perianth organs are retarded. Conversely, it seems that petal retardation is no longer present in core asterids with sympetalous flowers (Endress, 1994).

The other problem is that perianth organs often occur in more than two series, and, toward the periphery, they may gradually merge into more bract-like organs. This is especially pronounced when the floral organs are spirally arranged and the number is not fixed (Fig. 10A, B) (e.g., Amborella, Austrobaileya, Trimenia, and Chimonanthus) (Endress, 1980; Endress \& Sampson, 1983; Endress \& Igersheim, 2000). So where does the flower begin? Are the lowest organs of the floral axis floral organs or bracts? This problem is also present in some more basal eudicots, such as Ranunculales (Endress, 1995), Trochodendraceae (Endress, 1986), Buxaceae (von Balthazar \& Endress, 2002), and Myrothamnaceae (JägerZürn, 1966).

Larger-scale, comparative studies are certainly required in the new perspective of current knowledge. It is also to be hoped that molecular developmental genetic studies with an evolutionary focus as initiated in the past few years will shed light on these questions (Irish \& Kramer, 1998; Baum \& Whitlock, 1999; Kramer \& Irish, 1999, 2000). The recently initiated Floral Genome Project (Soltis et al., 2002) hopefully will contribute substantially to answering these questions. The better phylogenetic relationships are supported by molecular and combined studies, the more it will be possible to study the evolution of structural and biological traits. This will then be an eye-opener for evolutionary potentials in structure. It will support many of the earlier assumptions, but it will also show how some of the earlier, almost dogmatic assumptions in evolutionary morphology were wrong. Finally, the tough question of how flowers originated should also be tackled in a multifaceted effort (Hollingsworth et al., 1999; Donoghue \& Doyle, 2000; Frohlich \& Parker, 2000; Cronk et al., 2002).

\section{Conclusions: New Opportunities and Goals of Morphology in Plant Systematics and Evolutionary Biology}

Today, comparative morphology has new and more opportunities and goals than ever before. This is due primarily to the presence of molecular methods and techniques, which can be used as a tool and which - and this is especially significant-have brought considerable advancement in our phylogenetic understanding of the organisms. Increasing finds of well-preserved fossils and improved possibilities for collecting plants in the field in various parts of the world also contribute to the new opportunities in morphology.

The first opportunity is phylogenetic analysis, based on combined molecular and morphological data. Analyses of broad data sets are the most promising way to reach well-supported results in phylogenetic reconstruction. 

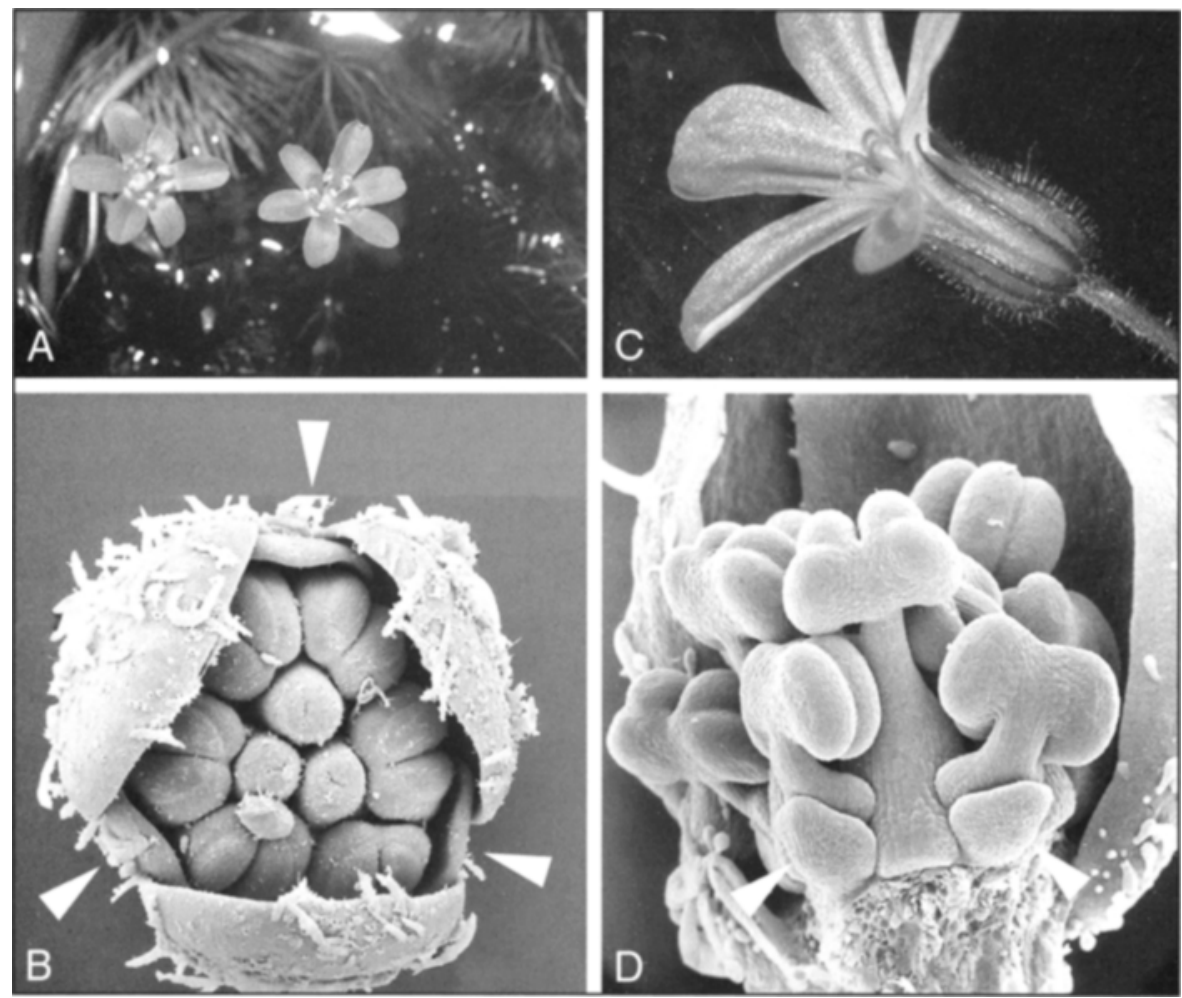

Fig. 9. Retardation of "petals" in floral buds in a representative of basal angiosperms and in one of core eudicots. A, B. Cabomba furcata (Cabombaceae, Nymphaeales). A. Flowers at anthesis. B. Floral bud (arrowheads point to retarded "petals"). C, D. Geranium robertianum (Geraniaceae, Geraniales). C. Flower at anthesis. D. Floral bud (arrowheads point to extremely retarded petals).

Second is evolutionary analysis of morphology, based on molecular (or combined molecular and morphological) phylogeny. As a first step, character-optimization programs can be used as a guideline for further evaluation of character evolution.

Third is refined analysis of morphological features, stimulated by inconsistencies in previous phylogenetic and evolutionary interpretations. At this stage, it becomes especially obvious how difficult and demanding morphological analysis really is.

Fourth is character optimization and judgment of morphological character evolution in a wider biological context. Character optimization using existing software gives only a initial framework for evolutionary interpretations. Even in well-supported cladograms, support for particular evolutionary character-state changes is often weak. Therefore, apparent evolutionary directions should be discussed in an omnispective biological evaluation.

Fifth is increased potential for including fossils in morphological analyses because of increased numbers and quality of fossil recoveries. Independently from newly available molecular techniques, paleobotany has made conspicuous progress. The many new fossils are indispensable tools for studying character evolution and approximating dates of branching points in clades at all levels. 


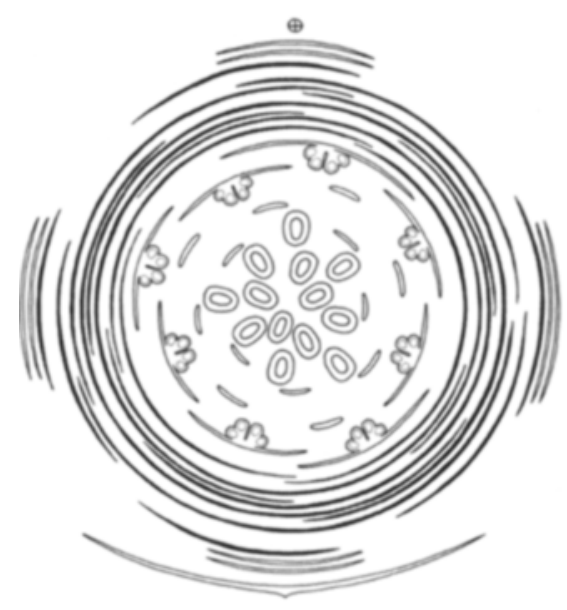

A

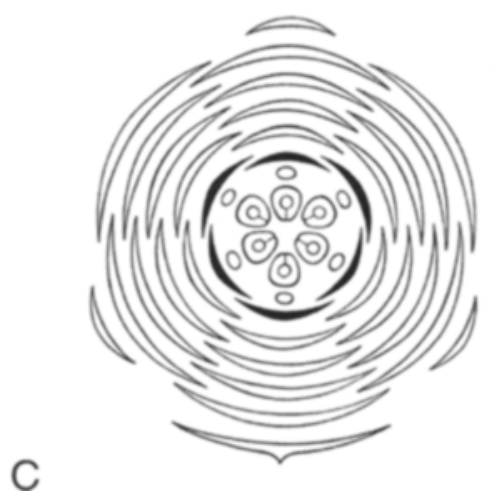

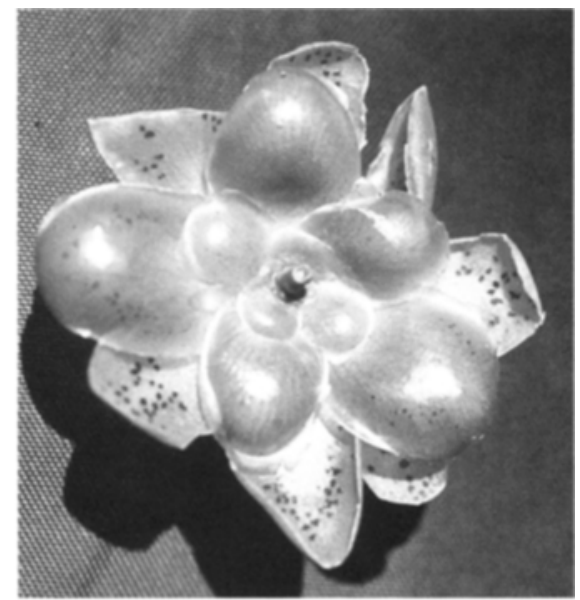

B

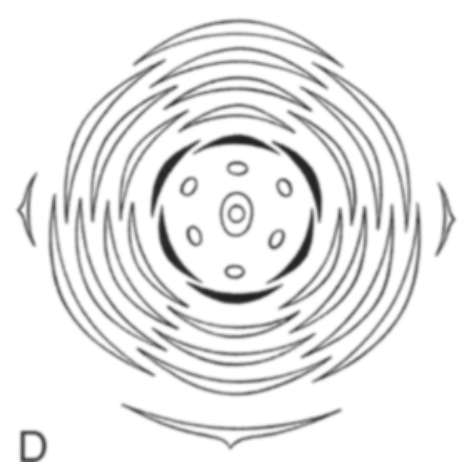

Fig. 10. Flowers that are preceded by bract-like organs so that delimitation of the flower toward the outside is problematic. A, B. Austrobaileya scandens (Austrobaileyaceae, ANITA grade). A. Floral diagram (from Endress, 1980). B. Flower from below. C, D. Floral diagrams of two representatives of Ranunculales (from Endress, 1995). C. Sciadotenia paraensis (Menispermaceae). D. Nandina domestica (Berberidaceae).

Sixth is exploration of the evolution of morphological traits through integration of comparative structural and molecular developmental genetic aspects (Evo-Devo). This field is still in its infancy in botany. Its advancement is one of the major goals of evolutionary botany for the future.

\section{Acknowledgment}

I thank Alex Bernhard for his support with the illustrations. 


\section{Literature Cited}

Albach, D. C., P. S. Soltis, D. E. Soltis \& R. G. Olmstead. 2001. Phylogenetic analysis of asterids based on sequences of four genes. Ann. Missouri Bot. Gard. 88: 163-212.

APG (Angiosperm Phylogeny Group). 1998. An ordinal classification for the families of flowering plants. Ann. Missouri Bot. Gard. 85: 531-553.

Bailey, I. W. 1956. The relationship between Sphenostemon of New Caledonia and Nouhuysia of New Guinea. J. Arnold Arbor. 37: 360-365.

\& B. G. L. Swamy. 1953. The morphology and relationships of Idenburgia and Nouhuysia. J. Arnold Arbor. 34: 77-85.

Baillon, H. 1875a. Stirpes exoticae novae. Adansonia 11: 292-312.

- 1875b. Sur le nouveau genre Sphenostemon. Bull. Mens. Soc. Linn. Paris 7: 53-54.

Baker, E. G. 1921. Systematic account of the plants collected in New Caledonia and the Isle of Pines by Prof. R. H. Compton, M.A., in 1914, I. Dicotyledons. Polypetalae. J. Linn. Soc., Bot., 45: 264-325.

Baum, D. A. \& B. A. Whitlock. 1999. Genetic clues to petal evolution. Curr. Biol. 9: 525-527.

Bernhard, A. \& P. K. Endress. 1999. Androecial development and systematics in Flacourtiaceae s.l. Pl. Syst. Evol. 215: 141-155.

Bradford, J. C. \& R. W. Barnes. 2001. Phylogenetics and classification of Cunoniaceae (Oxalidales) using chloroplast DNA sequences and morphology. Syst. Bot. 26: 354-385.

Bremer, B. \& J.-F. Manen. 2000. Phylogeny and classification of the subfamily Rubioideae (Rubiaceae). Pl. Syst. Evol. 225: 43-72.

—, K. Andreasen \& D. Olsson. 1995. Subfamilial and tribal relationships in the Rubiaceae based on $r b c L$ sequence data. Ann. Missouri Bot. Gard. 82: 383-397.

Bremer, K. 2000. Early Cretaceous lineages of monocot flowering plants. Proc. Natl. Acad. U.S.A. 97: $4707-4711$.

Caris, P., A. Vrijdaghs \& E. Smets. 2001. Floral ontogenetic studies in the former Ebenales. 15. Internationales Symposium Biodiversität \& Evolutionsbiologie, Ruhr-Universität Bochum, Germany. Poster.

Chase, M. W., D. E. Soltis, R. G. Olmstead, D. Morgan, D. H. Les, B. D. Mishler, M. R. Duvall, R. A. Price, H. G. Hills, Y.-L. Qiu, K. A. Kron, J. H. Rettig, E. Conti, J. D. Palmer, J. R. Manhart, K. J. Sytsma, H. J. Michaels, W. J. Kress, K. G. Karol, W. D. Clark, M. Hedén, B. S. Gaut, R. K. Jansen, K.-J. Kim, C. F. Wimpee, J. F. Smith, G. R. Furnier, S. H. Strauss, Q.-Y. Xiang, G. M. Plunkett, P. S. Soltis, S. M. Swensen, S. E. Williams, P. A. Gadek, C. J. Quinn, L. E. Eguiarte, E. Golenberg, G. H. Learn Jr., S. W. Graham, S. C. H. Barrett, S. Dayanandan \& V. A. Albert. 1993. Phylogenetics of seed plants: An analysis of nucleotide sequences from the plastid gene $r b c L$. Ann. Missouri Bot. Gard. 80: 528-580.

$\longrightarrow$, M. F. Fay \& V. Savolainen. 2000. Higher-level classification in the angiosperms: New insights from the perspective of DNA sequence data. Taxon 49: 685-704.

—, S. Zmarty, M. D. Lledó, K. J. Wurdack, S. M. Swensen \& M. F. Fay. 2002. When in doubt, put it in the Flacourtiaceae: A molecular phylogenetic analysis based on plastid $r b c L$ DNA sequences. Kew Bull. 57: 141-181.

Coen, E. S. 1996. Floral symmetry. EMBO J. 15: 6777-6788.

Conti, E., A. Litt \& K. J. Sytsma. 1996. Circumscription of Myrtales and their relationships to other rosids: Evidence from $r b c L$ sequence data. Amer. J. Bot. 83: 221-233.

—_ A. Litt, P. G. Wilson, S. A. Graham, B. G. Briggs, L. A. S. Johnson \& K. J. Sytsma. 1997. Interfamilial relationships in Myrtales: Molecular phylogeny and patterns of morphological evolution. Syst. Bot. 22: 629-647.

Costello, A. \& T. J. Motley. 2001. Molecular systematics of Tetraplasandra, Munroidendron and Reynoldsia sandwicensis (Araliaceae) and the evolution of superior ovaries in Tetraplasandra. Edinburgh J. Bot. 58: 229-242.

Crane, P. R., E. M. Friis \& K. R. Pedersen. 1995. The origin and early diversification of angiosperms. Nature 374: 27-33.

Cronk, Q. C. B., R. M. Bateman \& J. A. Hawkins (eds.). 2002. Developmental genetics and plant evolution. Taylor \& Francis, London. 
Cronquist, A. 1981. An integrative system of classification of flowering plants. Columbia Univ. Press, New York.

Cubas, P., C. Vincent \& E. S. Coen. 1999. An epigenetic mutation responsible for natural variation in floral symmetry. Nature 401: 157-161.

Dahlgren, R. M. T. \& K. Bremer. 1985. Major clades of the angiosperms. Cladistics 1: 349-368.

_, H. T. Clifford \& P. F. Yeo. 1985. The families of the monocotyledons: Structure, evolution, and taxonomy. Springer-Verlag, Berlin.

Dickison, W. C. 1967-1970. Comparative morphological studies in Dilleniaceae. Respective parts published in J. Arnold Arbor. as follows: I. Wood anatomy, 48: 1-23; II. The pollen, 48: 231-240; III. The carpels, 49: 317-332; IV. Anatomy of the node and vascularization of the leaf, 50: 384410 ; V. Leaf anatomy, 51: 89-113; VI. Stamens and young stem, 51: 403-422.

- 1975a. Studies on the floral anatomy of the Cunoniaceae. Amer. J. Bot. 62: 433-447.

- 1975b. Leaf anatomy of Cunoniaceae. Bot. J. Linn. Soc. 71: 275-294.

- 1977. Wood anatomy of Weinmannia (Cunoniaceae). Bull. Torrey Bot. Club 104: 12-23.

- 1978. Comparative anatomy of Eucryphiaceae. Amer. J. Bot. 65: 722-735.

-1979. A note on the wood anatomy of Dillenia (Dilleniaceae). IAWA Bull. 1979: 57-60.

- 1980. Diverse nodal anatomy of the Cunoniaceae. Amer. J. Bot. 67: 975-981.

- 1984. Fruits and seeds of the Cunoniaceae. J. Arnold Arboret. 65: 149-190.

1989. Comparisons of primitive Rosidae and Hamamelidae. Pp. 47-73 in P. R. Crane \& S. Blackmore (eds.), Evolution, systematics, and fossil history of the Hamamelidae. Vol. 1. Introduction and "Lower" Hamamelidae. Syst. Assoc., Clarendon Press, Oxford.

1993. Floral anatomy of the Styracaceae, including observations on intra-ovarian trichomes.

Bot. J. Linn. Soc. 112: 223-255.

. 2000. Integrative plant anatomy. Academic Press, San Diego, CA.

_ \& P. Baas. 1977. The morphology and relationships of Paracryphia (Paracryphiaceae). Blumea 23: 417-438.

\& R. Rutishauser. 1990. Developmental morphology of stipules and systematics of the Cunoniaceae and presumed allies, II. Taxa without interpetiolar stipules and conclusions. Bot. Helvet. 100: 75-95.

ecology and evolution. J. Amold Arbor. 59: 32-49.

Donoghue, M. J. 1994. Progress and prospects in reconstructing plant phylogeny. Ann. Missouri Bot. Gard. 81: 405-418.

_ \& J. A. Doyle. 1989a. Phylogenetic studies of seed plants and angiosperms based on morphological characters. Pp. 181-193 in B. Fernholm, K. Bremer \& H. Jörnvall (eds.), The hierarchy of life: Molecules and morphology in phylogenetic analysis. Excerpta Medica, Amsterdam and New York.

\& $1989 \mathrm{~b}$. Phylogenetic analysis of angiosperms and the relationships of Hamamelidae. Pp. 17-45 in P. R. Crane \& S. Blackmore (eds.), Evolution, systematics, and fossil history of the Hamamelidae. Vol. 1. Introduction and "Lower" Hamamelidae. Syst. Assoc., Clarendon Press, Oxford.

- 2000. Seed plant phylogeny: Demise of the anthophyte hypothesis? Curr. Biol. 10: R106-R109.

\& M. J. Sanderson. 1992. The suitability of molecular and morphological evidence in reconstructing plant phylogeny. Pp. 340-368 in P. S. Soltis, D. E. Soltis \& J. J. Doyle (eds.), Molecular systematics of plants. Chapman \& Hall, New York.

_ J J. A. Doyle, J. Gautier, A. G. Kluge \& T. Rowe. 1989. The importance of fossils in phylogeny reconstruction. Annual Rev. Ecol. Syst. 20: 431-460.

- R. H. Ree \& D. A. Baum. 1998. Phylogeny and evolution of flower symmetry in the Asteridae. Trends Pl. Sci. 3: 311-317.

Doyle, J. A. 1969. Cretaceous angiosperm pollen of the Atlantic coastal plain and its evolutionary significance. J. Arnold Arbor. 50: 1-35.

\& P. K. Endress. 2000. Morphological phylogenetic analysis of basal angiosperms: Comparison and combination with molecular data. Int. J. P1. Sci. 161: S121-S153. 
\& C. L. Hotton. 1991. Diversification of early angiosperm pollen in a cladistic context. Pp. 169-195 in S. Blackmore \& S. H. Barnes (eds.), Pollen and spores: Patterns of diversification. Syst. Assoc., Clarendon Press, Oxford.

, M. J. Donoghue \& E. A. Zimmer. 1994. Integration of morphological and ribosomal RNA data on the origin of angiosperms. Ann. Missouri Bot. Gard. 81: 419-450.

Doyle, J. J., J. A. Chappill, C. D. Bailey \& T. Kajita. 2000. Towards a comprehensive phylogeny of legumes: Evidence from $r b c L$ sequences and non-molecular data. Pp. 1-20 in P. S. Herendeen \& A. Bruneau (eds.), Advances in legume systematics, Part 9. Roy. Bot. Gard., Kew.

Drinnan, A. N., P. R. Crane \& S. B. Hoot. 1994. Patterns of floral evolution in the early diversification of non-magnoliid dicotyledons (eudicots). Pl. Syst. Evol., Suppl. 8: 93-122.

Endress, P. K. 1969. Gesichtspunkte zur systematischen Stellung der Eupteleaceen (Magnoliales). Ber. Schweiz. Bot. Ges. 79: 229-278.

. 1980. The reproductive structures and systematic position of the Austrobaileyaceae. Bot. Jahrb. Syst. 101: 393-433.

. 1986. Floral structure, systematics and phylogeny in Trochodendrales. Ann. Missouri Bot. Gard. 73: $297-324$.

-1989a. Aspects of evolutionary differentiation of the Hamamelidaceae and the lower Hamamelididae. Pl. Syst. Evol. 162: 193-211.

- 1989b. Phylogenetic relationships in the Hamamelidoideae. Pp. 227-248 in P. R. Crane \& S. Blackmore (eds.), Evolution, systematics, and fossil history of the Hamamelidae. Vol. 2. "Higher" Hamamelidae. Syst. Assoc., Clarendon Press, Oxford.

1994. Diversity and evolutionary biology of tropical flowers. Cambridge Univ. Press, Cambridge. 1995. Floral structure and evolution in Ranunculanae. Pp. 47-61 in U. Jensen \& J. W. Kadereit (eds.), Systematics and evolution of the Ranunculiflorae. Pl. Syst. \& Evol., Suppl. 9. SpringerVerlag, Vienna.

1998. Antirrhinum and Asteridae-Evolutionary changes of floral symmetry. Symp. Ser. Soc. Exp. Biol. 53: 133-140.

- 1999. Symmetry in flowers: Diversity and evolution. Int. J. PI. Sci. 160: S3-S23.

2001a. Evolution of floral symmetry. Curr. Opin. Pl. Biol. 4: 86-91.

2001b. The flowers in extant basal angiosperms and inferences on ancestral flowers. Int. J. P1. Sci. 162: 1111-1140.

\& A. Igersheim. 1999. Gynoecium diversity and systematics of the basal eudicots. Bot. J. Linn. Soc. 130: 305-393

- $\&-2000$. The reproductive structures of the basal angiosperm Amborella trichopoda (Amborellaceae). Int. J. P1. Sci. 161: S237-S248.

\& F. B. Sampson. 1983. Floral structure and relationships of the Trimeniaceae (Laurales). J. Arnold Arbor. 64: 447-473.

__ M. Jenny \& M. E. Fallen. 1983. Convergent elaboration of apocarpous gynoecia in higher advanced dicotyledons (Sapindales, Malvales, Gentianales). Nord. J. Bot. 3: 293-300.

__ P. Baas \& M. Gregory. 2000. Systematic plant morphology and anatomy-50 years of progress. Taxon 49: 401-434.

Engler, A. 1930. Saxifragaceae. Pp. 74-226 in A. Engler \& K. Prantl (eds.), Die natürlichen Pflanzenfamilien, Vol. 18a. Ed. 2. W. Engelmann, Leipzig.

Erbar, C. 1986. Untersuchungen zur Entwicklung der spiraligen Blüte von Stewartia pseudocamellia (Theaceae). Bot. Jahrb. Syst. 106: 391-407.

Eyde, R. H. \& C. C. Tseng. 1969. Flower of Tetraplasandra gymnocarpa: Hypogyny with epigynous ancestry. Science 166: 506-508.

- \& 1971. What is the primitive floral structure of Araliaceae? J. Arnold Arbor. 52: 205-239.

Fay, M. F., B. Bremer, G. T. Prance, M. van der Bank, D. Bridson \& M. W. Chase. 2000. Plastid $r b c L$ sequence data show Dialypetalanthus to be a member of Rubiaceae. Kew Bull. 55: 853-864.

Friis, E. M., K. R. Pedersen \& P. R. Crane. 1994. Angiosperm floral structures from the Early Cretaceous of Portugal. Pl. Syst. Evol., Suppl. 8: 31-49.

,$--\& \longrightarrow$ 2000. Reproductive structure and organization of basal angiosperms from the Early Cretaceous (Barremian or Aptian) of Portugal. Int. J. Pl. Sci. 161: S169-S182. 
$\longrightarrow,-2001$. Fossil evidence of water lilies in the Early Cretaceous. Nature 410: $357-360$.

Frohlich, M. W. \& D. S. Parker. 2000. The mostly male theory of flower evolutionary origins: From genes to fossils. Syst. Bot. 25: 155-170.

Gibbs, L. S. 1917. Dutch N.W. New Guinea: A contribution to the phytogeography and flora of the Arfak Mountains, \&c. Taylor and Frances, London.

Gilg, E. \& E. Werdermann. 1925. Marcgraviaceae. Pp. 94-106 in A. Engler \& K. Prantl (eds.), Die natürlichen Pflanzenfamilien, Vol. 21. Ed. 2. W. Engelmann, Leipzig.

Gustafsson, M. H. G. \& V. A. Albert. 1999. Inferior ovaries and angiosperm diversification. Pp. 403431 in P. M. Hollingsworth, R. M. Bateman \& R. J. Gornall (eds.), Molecular systematics and plant evolution. Taylor \& Francis, London.

Hallier, H. 1903. Über den Umfang, die Gliederung und die Verwandtschaft der Familie der Hamamelidaceen. Beih. Bot. Centralbl. 14: 247-260.

Hawkins, J. A. 2000. A survey of primary homology assessment: Different botanists perceive and define characters in different ways. Pp. 22-53 in R. Scotland \& R. T. Pennington (eds.), Homology and systematics: Coding characters for phylogenetic analysis. Taylor \& Francis, London.

Henrickson, J. 1972. A taxonomic revision of the Fouquieriaceae. Aliso 7: 439-537.

Hiepko, P. 1965. Vergleichend-morphologische und entwicklungsgeschichtliche Untersuchungen über das Perianth bei den Polycarpicae. Bot. Jahrb. Syst. 84: 359-508.

Hirmer, M. 1918. Beiträge zur Morphologie der polyandrischen Blüten. Flora 110: 140-192.

Hollingsworth, P. M., R. M. Bateman \& R. J. Gornall (eds.). 1999. Molecular systematics and plant evolution. Taylor \& Francis, London.

Hoot, S. B. \& P. R. Crane. 1995. Inter-familial relationships in the Ranunculidae based on molecular systematics. Pp. 119-131 in U. Jensen \& J. W. Kadereit (eds.), Systematics and evolution of the Ranunculiflorae. P1. Syst. \& Evol., Suppl. 9. Springer-Verlag, Vienna.

Huber, K. 1980. Morphologische und entwicklungsgeschichtliche Untersuchungen an Blüten und Blütenständen von Solanaceen und von Nolana paradoxa Lindl. (Nolanaceae). Diss. Bot. 55: 1252.

Hufford, L. 1990. Androecial development and the problem of monophyly of Loasaceae. Canad. J. Bot. 68: $402-419$.

-1992. Rosidae and their relationships to other nonmagnoliid dicotyledons: A phylogenetic analysis using morphological and chemical data. Ann. Missouri Bot. Gard. 79: 218-248.

. 1997. A phylogenetic analysis of Hydrangeaceae based on morphological data. Int. J. P1. Sci. 158: $652-672$.

\& W. C. Dickison. 1992. A phylogenetic analysis of Cunoniaceae. Syst. Bot. 17: 181-192. quences of the plastid gene matK and their combination with $r b c L$ and morphological data. Int. J. Pl. Sci. 162: 835-846.

Hughes, N. F. \& A. B. McDougall. 1987. Records of angiospermid pollen entry into the English Early Cretacous succession. Rev. Paleobot. Palynol. 50: 255-272.

Igersheim, A., C. Puff, P. Leins \& C. Erbar. 1994. Gynoecial development of Gaertnera Lam. and of presumably allied taxa of the Psychotrieae (Rubiaceae): Secondarily "superior" vs. inferior ovaries. Bot. Jahrb. Syst. 116: 401-414.

Irish, V. F. \& E. M. Kramer. 1998. Genetic and molecular analysis of angiosperm flower development. Advances Bot. Res. 28: 197-230.

Jäger-Zürn, I. 1966. Infloreszenz- und blütenmorphologische, sowie embryologische Untersuchungen an Myrothamnus Welw. Beitr. Biol. Pflanzen 42: 241-271.

Jérémie, J. 1997. Sphenostemonaceae. Pp. 3-21 in P. Morat (ed.), Flore de la Nouvelle Calédonie, 21. Muséum National d'Histoire Naturelle, Paris.

Juncosa, A. M. 1988. Floral development and character evolution in Rhizophoraceae. Pp. 83-101 in P. Leins, S. C. Tucker \& P. K. Endress (eds.), Aspects of floral development. J. Cramer, Berlin.

Kappeler, G. 1995. Anlage des Androeciums bei einigen Vertretern der Hydrangeaceae. Abstr. 12. Symposium Morphologie, Anatomie und Systematik, Univ. of Mainz, Mainz.

Kramer, E. M. \& V. F. Irish. 1999. Evolution of genetic mechanisms controlling petal development. Nature 399: 144-148. 
$\boldsymbol{\&}$

2000. Evolution of the petal and stamen developmental programs: Evidence from comparative studies of the lower eudicots and basal angiosperms. Int. J. Pl. Sci. 161: S29-S40.

Kubitzki, K., J. G. Rohwer \& V. Bittrich (eds.). 1993. The families and genera of vascular plants. Vol. 2. Flowering plants, dicotyledons: Magnoliid, hamamelid, and caryophyllid families. SpringerVerlag, Berlin.

Kuzoff, R. K., D. E. Soltis, L. Hufford \& P. S. Soltis. 1999. Phylogenetic relationships within Lithophragma (Saxifragaceae): Hybridization, allopolyploidy, and ovary diversification. Syst. Bot. 24: 598-615.

—_ L. Hufford \& D. E. Soltis. 2001. Structural homology and developmental transformations associated with ovary diversification in Lithophragma (Saxifragaceae). Amer. J. Bot. 88: 196-205.

Lauterbach, C. 1912. Guttiferae. Nova Guinea 8: 843-844.

Leeuwenberg, A. J. M. \& P. W. Leenhouts. 1980. Taxonomy [Loganiaceae]. Pp. 8-96 in A. Engler \& K. Prantl (eds.), Die natürlichen Pflanzenfamilien, Vol. 28b. Ed. 2. I. Duncker \& Humblot, Berlin.

Leins, P. 1972. Das zentrifugale Androeceum von Couroupita guianensis (Lecythidaceae). Beitr. Biol. Pflanzen 48: 313-319.

\& C. Erbar. 1995. Das frühe Differenzierungsmuster in den Blüten von Saruma henryi Oliv. (Aristolochiaceae). Bot. Jahrb. Syst. 117: 365-376.

\& W. Winhard. 1973. Entwicklungsgeschichtliche Studien an Loasaceen-Blüten. Oesterr. Bot. Z. 122: $145-165$.

Li, J.-H. \& A. L. Bogle. 2001. A new suprageneric classification system of the Hamamelidoideae based on morphology and sequences of nuclear and chloroplast DNA. Harvard Pap. Bot. 5: 499-515.

Magallón, S., P. R. Crane \& P. S. Herendeen. 1999. Phylogenetic pattern, diversity, and diversification of eudicots. Ann. Missouri Bot. Gard. 86: 297-372.

Matthews, M. L., P. K. Endress, J. Schönenberger \& E. M. Friis. 2001. A comparison of floral structures of Anisophylleaceae and Cunoniaceae and the problem of their systematic position. Ann. Bot. (London) 88: 439-455.

McDade, L. A., S. E. Masta, M. L. Moody \& E. Waters. 2000. Phylogenetic relationships among Acanthaceae: Evidence from two genomes. Syst. Bot. 25: 106-121.

Mennega, A. M. W. 1980. Anatomy of the secondary phloem [Loganiaceae]. Pp. 15-65 in A. Engler \& K. Prantl (eds.), Die natürlichen Pflanzenfamilien, Vol. 28b. Ed. 2. I. Duncker \& Humblot, Berlin.

Metcalfe, C. R. 1956. The taxonomic affinities of Sphenostemon in the light of the anatomy of its stem and leaf. Kew Bull. 1956: 249-253.

Mohr, B. A. R. \& E. M. Friis. 2000. Early angiosperms from the Lower Cretaceous Crato Formation (Brazil): A preliminary report. Int. J. Pl. Sci. 161: S155-S167.

Möller, M., M. Clokie, P. Cubas \& Q. C. B. Cronk. 1999. Integrating molecular phylogenies and developmental genetics. A Gesneriaceae case study. Pp. 375-402 in P. M. Hollingsworth, R. M. Bateman \& R. J. Gornall (eds.), Molecular systematics and plant evolution. Taylor \& Francis, London.

Moody, M. L. \& L. Hufford. 2000. Floral ontogeny and morphology of Cevallia, Fuertesia, and Gronovia (Loasaceae subfamily Gronovioideae). Int. J. Pl. Sci. 161: 869-883.

$\longrightarrow,-$, D. E. Soltis \& P. S. Soltis. 2001. Phylogenetic relationships of Loasaceae subfamily Gronovioideae inferred from $m a t K$ and ITS sequence data. Amer. J. Bot. 88: 326-336.

Morley, B. \& J.-M. Chao. 1977. A review of Corylopsis (Hamamelidaceae). J. Arnold Arbor. 58: 382414.

Nandi, O. I., M. W. Chase \& P. K. Endress. 1998. A combined cladistic analysis of angiosperms using $r b c L$ and nonmolecular data sets. Ann. Missouri Bot. Gard. 85: 137-212.

Olmstead, R. G., B. Bremer, K. M. Scott \& J. D. Palmer. 1993. A parsimony analysis of the Asteridae sensu lato based on $r b c L$ sequences. Ann. Missouri Bot. Gard. 80: 700-722.

Piesschaert, F., E. Robbrecht \& E. Smets. 1997. Dialypetalanthus fuscescens Kuhlm. (Dialypetalanthaceae): The problematic taxonomic position of an Amazonian endemic. Ann. Missouri Bot. Gard. 84: 201-223.

Plunkett, G. M. \& P. P. Lowry II. 2001. Relationships among "ancient araliads" and their significance for the systematics of Apiales. Molec. Phylogenet. Evol. 19: 259-276.

, D. E. Soltis \& P. S. Soltis. 1997. Clarification of the relationship between Apiaceae and Araliaceae based on $m a t K$ and $r b c L$ sequence data. Amer. J. Bot. 84: 565-580. 
Qiu, Y.-L., J. Lee, F. Bernasconi-Quadroni, D. E. Soltis, P. S. Soltis, M. Zanis, E. A. Zimmer, Z. Chen, V. Savolainen \& M. W. Chase. 1999. The earliest angiosperms: Evidence from mitochondrial, plastid and nuclear genomes. Nature 402: 404-407.

Rao, T. A. \& W. C. Dickison. 1985a. The veinsheath syndrome in Cunoniaceae, 1. Pancheria Brongn. \& Gris. Proc. Indian Acad. Sci. Pl. Sci. 95: 87-94.

___ 1985b. The veinsheath syndrome in Cunoniaceae, II. The genera Acsmithia, Codia, Cunonia, Geissois, Pullea and Weinmannia. Proc. Indian Acad. Sci. Pl. Sci. 95: 247-261.

Ree, R. H. \& M. J. Donoghue. 1999. Inferring rates of change in flower symmetry in asterid angiosperms. Syst. Biol. 48: 633-641.

Reeves, P. A. \& R. G. Olmstead. 1998. Evolution of novel morphological, ecological, and reproductive traits in a clade containing Antirrhinum. Amer. J. Bot. 85: 1047-1056.

Robbrecht, E. 1988. Tropical woody Rubiaceae: Characteristic features and progressions: Contributions to a new subfamilial classification. Opera Bot. Belg. 1: 1-271.

Roels, P., L. P. Ronse Decraene \& E. F. Smets. 1997. A floral ontogenetic investigation of the Hydrangeaceae. Nord. J. Bot. 17: 235-254.

Ronse Decraene, L. P., H. P. Linder, T. Dlamini \& E. F. Smets. 2001. Evolution and development of floral diversity of Melianthaceae, an enigmatic Southern African family. Int. J. Pl. Sci. 162: 59-82.

Rury, P. M. \& W. C. Dickison. 1977. Leaf venation patterns of the genus Hibbertia (Dilleniaceae). J. Arnold Arbor. 58: 209-241.

Rutishauser, R. \& W. C. Dickison. 1989. Developmental morphology of stipules and systematics of the Cunoniaceae and presumed allies, I. Taxa with interpetiolar stipules. Bot. Helvet. 99: 147-169.

_ L L. P. Ronse Decraene, E. Smets \& I. Mendoza-Heuer. 1998. Theligonum cynocrambe: Developmental morphology of a peculiar rubiaceous herb. PI. Syst. Evol. 210; 1-24.

Sanderson, M. J. \& J. A. Doyle. 2001. Sources of error and confidence intervals in estimating the age of angiosperms from $r b c L$ and $18 \mathrm{~S}$ rDNA data. Amer. J. Bot. 88: 1499-1516.

Savolainen, V., M. F. Fay, D. C. Albach, A. Backlund, M. van der Bank, K. M. Cameron, S. A. Johnson, M. D. Lledó, J.-C. Pintaud, M. Powell, M. C. Sheahan, D. E. Soltis, P. S. Soltis, P. Weston, W. M. Whitten, K. J. Wurdack \& M. W. Chase. 2000. Phylogeny of the eudicots: A nearly complete familial analysis based on $r b c L$ gene sequences. Kew Bull. 55: 257 309.

Schlechter, R. 1906. Beiträge zur Kenntnis der Flora von Neu-Kaledonien. Bot. Jahrb. Syst. 39: 1-274.

Schmid, R. 1978. Actinidiaceae, Davidiaceae, and Paracryphiaceae: Systematic considerations. Bot. Jahrb. Syst. 100: 196-204.

Schönenberger, J. \& P. K. Endress. 1998. Structure and development of the flowers in Mendoncia, Pseudocalyx, and Thunbergia (Acanthaceae) and their systematic implications. Int. J. Pl. Sci. 159: 446-465.

- E. M. Friis, M. L. Matthews \& P. K. Endress. 2001. Cunoniaceae in the Cretaceous of Europe: Evidence from fossil flowers. Ann. Bot. (London) 88: 423-437.

Schwarzbach, A. E. \& R. E. Rickleffs. 2000. Systematic affinities of Rhizophoraceae and Anisophylleaceae, and intergeneric relationships within Rhizophoraceae, based on chloroplast DNA, nuclear ribosomal DNA, and morphology. Amer. J. Bot. 87: 547-564.

Simpson, M. G. 1994. Reversal of ovary position in the Haemodoraceae and its adaptive significance. Amer. J. Bot. (Suppl.) 81(6): 185 (abstract).

. 1998. Reversal in ovary position from inferior to superior in the Haemodoraceae: Evidence from floral ontogeny. Int. J. Pl. Sci. 159: 466-479.

Soltis, D. E., P. S. Soltis, D. L. Nickrent, L. A. Johnson, W. J. Hahn, S. B. Hoot, J. A. Sweere, R. K. Kuzoff, K. A. Kron, M. W. Chase, S. M. Swensen, E. A. Zimmer, S.-M. Chaw, L. J. Gillespie, W. J. Kress \& K. J. Sytsma. 1997. Angiosperm phylogeny inferred from 18 S ribosomal DNA sequences. Ann. Missouri Bot. Gard. 84: 1-49.

,$- \longrightarrow$ M. W. Chase, M. E. Mort, D. C. Albach, M. Zanis, V. Savolainen, W. H. Hahn, S. B. Hoot, M. F. Fay, M. Axtell, S. M. Swensen, L. M. Prince, W. J. Kress, K. C. Nixon \& J. S. Farris. 2000. Angiosperm phylogeny inferred from $18 \mathrm{~S}$ rDNA, $r b c L$, and $a t p B$ sequences. Bot. J. Linn. Soc. 133: 381-461.

, M. Tago-Nakazawa, Q.-Y. Xiang, S. Kawano, J. Murata, M. Wakabayashi \& C. HibschJetter. 2001. Phylogenetic relationships and evolution in Chrysosplenium (Saxifragaceae) based on matK sequence data. Amer. J. Bot. 88: 883-893. 
, P. S. Soltis, V. A. Albert, D. G. Oppenheimer, C. W. dePamphilis, H. Ma, M. W. Frohlich \&

G. Theissen. 2002. Missing links: The genetic architecture of flowers and floral diversification. Trends Pl. Sci. 7: 22-31.

Soltis, P. S. \& D. E. Soltis. 1993. Ancient DNA: Prospects and limitations. New Zealand J. Bot. 31: 203-209.

Stevens, P. F. 1991. Character states, morphological variation, and phylogenetic analysis: A review. Syst. Bot. 16: 553-583.

2000. On characters and characters states: Do overlapping and non-overlapping variation, morphology and molecules all yield data of the same value? Pp. 81-105 in R. Scotland \& R. T. Pennington (eds.), Homology and systematics: Coding characters for phylogenetic analysis. Taylor \& Francis, London.

Stevenson, D. W., J. D. Davis, J. V. Freudenstein, C. R. Hardy, M. P. Simmons \& C. D. Specht. 2000. A phylogenetic analysis of the monocotyledons based on morphological and molecular character sets, with comments on the placement of Acorus and Hydatellaceae. Pp. 17-24 in K. L. Wilson \& D. A. Morrison (eds.), Monocots: Systematics and evolution. CSIRO, Melbourne, Australia.

Steyn, E. M. A., P. J. Robbertse \& L. A. Coetzer. 1991. Intra-ovarian trichomes in Bequaertiodendron magalismontanum: Location, origin, structure and possible function in the reproductive process. S. African J. Bot. 57: 191-197.

Suessenguth, K. 1927. Über die Gattung Lennoa: Ein Beitrag zur Kenntnis exotischer Parasiten. Flora 122: 264-301.

Sugiyama, M. 1991. Scanning electron microscopy observation on early ontogeny of the flower of Camellia japonica L. J. Jap. Bot. 66: 295-299.

Swamy, B. G. L. 1953. Comments on Ascarina alticola Schlechter. Proc. Natl Inst. Sci. India 19: 143-147.

Sytsma, K. J. \& W. J. Hahn. 2000. Molecular systematics. Progr. Bot. 62: 307-339.

\& J. C. Pires. 2001. Plant systematics in the next 50 years: Re-mapping the new frontier. Taxon 50: 713-732.

Takhtajan, A. 1959. Die Evolution der Angiospermen. G. Fischer, Jena, Germany. - 1997. Diversity and classification of flowering plants. Columbia Univ. Press, New York.

Thorne, R. F. 2000. The classification and geography of the flowering plants: Dicotyledons of the class Angiospermae (subclasses Magnoliidae, Ranunculidae, Caryophyllidae, Dilleniidae, Rosidae, Asteridae, and Lamiidae). Bot. Rev. (Lancaster) 66: 441-647.

Tsou, C.-H. 1994. The embryology, reproductive morphology, and systematics of Lecythidaceae. Mem. New York Bot. Gard., 71. New York Bot. Gard., Bronx.

. 1998. Early floral development of Camellioideae (Theaceae). Amer. J. Bot. 85: 1531-1547.

Tucker, S. C. \& A. W. Douglas. 1994. Ontogenetic evidence and phylogenetic relationships among basal taxa of legumes. Pp. 11-32 in I. K. Ferguson \& S. C. Tucker (eds.), Advances in legume systematics. Part 6. Structural botany. Roy. Bot. Gard., Kew.

$\longrightarrow \&-1996$. Floral structure, development, and relationships of paleoherbs: Saruma, Cabomba, Lactoris, and selected Piperales. Pp. 141-175 in D. W. Taylor \& L. J. Hickey (eds.), Flowering plant origin, evolution and phylogeny. Chapman \& Hall, New York.

Upchurch, G. R., Jr. 1984. Cuticle evolution in Early Cretaceous angiosperms from the Potomac Group of Virginia and Maryland. Ann. Missouri Bot. Gard. 71: 522-550.

Van Heel, W. A. 1987. Androecium development in Actinidia chinensis and A. melanandra (Actinidiaceae). Bot. Jahrb. Syst. 109: 17-23.

Van Steenis, C. G. G. J. 1950. Note on Paracryphia Baker (Eucryphiaceae). Bull. Bot. Gard. Buitenzorg, ser. 3, 18: 459.

- 1952. Reduction of two endemic monotypic Papuan genera. Acta Bot. Neerl. 1: 93-98.

1955. Some notes on the flora of New Caledonia and reduction of Nouhuysia to Sphenostemon. Svensk Bot. Tidskr. 49: 19-23.

Vinnersten, A. \& K. Bremer. 2001. Age and biogeography of major clades in Liliales. Amer. J. Bot. 88: $1695-1703$.

Vishenskaya, T. D. 1980a. Polymerous androecium and its development in the flower of Thea sinensis

L. (Theaceae). Bot. Zhurn. (Moscow \& Leningrad) 65: 39-50.

. $1980 \mathrm{~b}$. The development of the polymerous androecium in Stuartia pseudocamellia (Theaceae).

Bot. Zhurn. (Moscow \& Leningrad) 65: 948-957. 
Von Balthazar, M. \& P. K. Endress. 2002. Development of inflorescences and flowers in Buxaceae and the problem of perianth interpretation. Int. J. Pl. Sci. 163: 847-876.

Von Hagen, K. B. \& J. W. Kadereit. 2002. Phylogeny and flower evolution of the Swertinae (Gentianaceae-Gentianeae): Homoplasy and the principle of variable proportions. Syst. Bot. 27: 548-572.

Wanntorp, L., H.-E. Wanntorp, B. Oxelman \& M. Källersjö. 2001. Phylogeny of Gunnera. Pl. Syst. Evol. 226: 85-107.

Wen, J., G. M. Plunkett, A. D. Mitchell, S. J. Wagstaff. 2001. The evolution of Araliaceae: A phylogenetic analysis based on ITS sequences of nuclear ribosomal DNA. Syst. Bot. 26: 144-167.

Wilkinson, H. P. 2000. A revision of the anatomy of Gunneraceae. Bot. J. Linn. Soc. 134: 233-266. 